\title{
LEAF LIFE-SPAN IN RELATION TO LEAF, PLANT, AND STAND CHARACTERISTICS AMONG DIVERSE ECOSYSTEMS ${ }^{1}$
}

\author{
P. B. ReICH AND M. B. WALters \\ Department of Forest Resources, University of Minnesota, St. Paul, Minnesota 55108 USA \\ D. S. ELLSWORTH \\ Department of Botany, University of Vermont, Burlington, Vermont 05405 USA
}

\begin{abstract}
Variation in leaf life-span has long been considered of ecological significance. Despite this, quantitative evaluation of the relationships between leaf life-span and other plant and ecosystem characteristics has been rare. In this paper we ask whether leaf lifespan is related to other leaf, plant, and stand traits of species from diverse ecosystems and biomes. We also examine the interaction between leaf, plant, and stand traits and their relation to productivity and ecological patterns.

Among all species, both mass- $\left(A_{\text {mass }}\right)$ and area-based ( $\left.A_{\text {area }}\right)$ maximum net photosynthesis decreased with increasing leaf life-span, but the relationship was stronger on a mass $\left(P<.001, r^{2}=0.70\right)$ than an area $\left(P<.05, r^{2}=0.24\right)$ basis. Similarly, mass-based leaf nitrogen (leaf $\left.\mathrm{N}_{\text {mass }}\right)$ decreased $\left(P<.001, r^{2}=0.52\right)$ with leaf life-span, but area-based leaf $\mathrm{N}$ (leaf $\mathrm{N}_{\text {area }}$ ) did not $\left(P>.25, r^{2}=0.01\right)$. Specific leaf area (SLA, leaf area/leaf dry mass) and leaf diffusive conductance also decreased with increasing leaf life-span. Decreasing $A_{\text {mass }}$ with increasing leaf life-span results from the impact of decreasing $\mathrm{N}_{\text {mass }}$ and SLA on $A_{\text {mass }}$. Variation in leaf traits as a function of leaf life-span was similar for broad-leaved and needle-leaved subsets of the data. These leaf-scale data from several biomes were compared to a data set from a single biome, Amazonia. For several leaf traits (e.g., SLA, $\mathrm{N}_{\text {mass }}$, and $A_{\text {mass }}$ ) the quantitative relationship with leaf life-span was similar in the two independent data sets, suggesting that these are fundamental relations applicable to all species. $A_{\text {mass }}$ was a linear function of $\mathrm{N}_{\text {mass }}\left(P<.001, r^{2}=0.74\right)$ with a regression similar to previous analyses, while $A_{\text {area }}$ was not significantly related to $\mathrm{N}_{\text {area }}$. These results suggest that the photosynthesis-leaf $\mathrm{N}$ relationship among species should be considered universal when expressed on a mass, but not on a leaf area, basis.

Relative growth rates (RGR) and leaf area ratio (LAR, the whole-plant ratio of leaf area to total dry mass) of seedlings decreased with increasing leaf life-span $\left(P<.001, r^{2}\right.$ $=0.61$ and 0.89 , respectively). LAR was positively related to both RGR and $A_{\text {mass }}\left(r^{2}=\right.$ 0.68 and 0.84 , respectively), and $A_{\text {mass }}$ and RGR were also positively related $\left(r^{2}=0.55\right)$. Absolute height growth rates of young trees decreased with increasing leaf life-span $(P<$ $\left..001, r^{2}=0.72\right)$ and increased with $A_{\text {mass }}\left(P<.001, r^{2}=0.78\right)$. It appears that a suite of traits including short leaf life-span and high leaf $\mathrm{N}_{\text {mass }}, \mathrm{SLA}, \mathrm{LAR}$, and $A_{\text {mass }}$ interactively contribute to high growth rates in open-grown individuals.

These traits interact similarly at the stand level, but stands differ from individuals in one key trait. In closed-canopy forests, species with longer lived foliage (and low LAR as seedlings) have greater foliage mass per unit ground area $\left(P<.001, r^{2}=0.74\right)$ and a greater proportion of total mass in foliage. The aboveground production efficiency (ANPP/foliar biomass) of forest stands decreased markedly with increasing leaf life-span or total foliage mass $\left(P<.001, r^{2}=0.78\right.$ and 0.72 , respectively), probably as a result of decreasing $A_{\text {mass}}$, $\mathrm{N}_{\text {mass }}$, and SLA, all of which were positively related with production efficiency and negatively related to total foliage mass. However, high foliage mass of species with extended leaf life-spans appears to compensate for low production per unit foliage, since aboveground net primary production (ANPP, in megagrams per hectare per year) of forest stands was not related to leaf life-span. Extended leaf life-span also appears to compensate for lower potential production per unit leaf $\mathrm{N}$ per unit time, with the result that stand-level $\mathrm{N}$ use efficiency is weakly positively related to leaf life-span.

We hypothesize that co-variation among species in leaf life-span, SLA, leaf $\mathrm{N}_{\text {mass }}, A_{\text {mass }}$, and growth rate reflects a set of mutually supporting traits that interact to determine plant behavior and production, and provide a useful conceptual link between processes at shortterm leaf scales and longer term whole plant and stand-level scales. Although this paper
\end{abstract}

\footnotetext{
${ }^{1}$ Manuscript received 5 March 1991; revised 16 August 1991; accepted 16 November 1991; final version received 19 December 1991.
} 
has focused on leaf life-span, this trait is so closely interrelated with several others that this cohort of leaf traits should be viewed as causally interrelated. Generality in the relationships between leaf life-span and other plant traits across diverse communities and ecosystems suggests that they are universal in nature and thus can provide a quantitative link and/or common currency for ecological comparisons among diverse systems.

Key words: height growth; leaf life-span; nitrogen; photosynthesis; primary production; scales; specific leaf area.

\section{INTRODUCTION}

Numerous studies have examined the carbon and nutrient relationships of plants at various hierarchical scales. Several reviews have provided a general understanding of certain aspects of such topics (e.g., Bazzaz 1979, Chapin 1980, Vitousek 1982, Coley et al. 1985, Field and Mooney 1986, Vogt et al. 1986, Hunt and Lloyd 1987, Raich and Nadelhoffer 1989). Despite these advances, many uncertainties remain, including an incomplete understanding of variation among species in carbon gain and nutrient use, especially with respect to linkages between leaf-level, plant-level, and ecosystem-level scales. In this paper we explore the potential significance of leaf life-span as an "ecological integrator" by examining the role of leaf life-span in relation to broad-scale variation in leaf, plant, and stand-level processes. We also consider the relationships among a suite of mutually supporting plant traits, including leaf life-span, photosynthetic rate, specific leaf area (SLA; leaf area to dry mass ratio), and leaf nitrogen $(\mathrm{N})$ concentration, and provide evidence for broad relationships between such traits and plant growth rates and stand-level processes.

Leaf life-span is an important life history trait of plants with respect to their growth and response to light, nutrient availability, drought, herbivory, air pollution, and other factors (Monk 1966, Small 1972, Chapin 1980, Gray and Schlesinger 1983, Reich 1987, Coley 1988). It has long been recognized that leaf lifespan is related in a general sense to other leaf traits such as photosynthesis or nutrient content (e.g., Chabot and Hicks 1982, Mooney and Gulmon 1982), but quantitative evaluation of such relations is lacking. Thus the specific forms and strengths of such relationships, as well as their generality and variability among species across diverse communities, are unknown. On a larger scale, leaf life-span is an important variable in comparisons of stand-level productivity, nutrient circulation, and decomposition between evergreen and deciduous forests (e.g., Bray and Gorham 1964, Gosz 1981, Vogt et al. 1986, Sprugel 1989, Gower and Richards 1990), but is usually difficult to separate from leaf form (broad- vs. needle-leaved).

The geographic distribution of communities dominated by evergreen or deciduous species has attracted lasting attention from ecologists (e.g., Axelrod 1966, Waring and Franklin 1979, Gower and Richards 1990). In general, deciduous species appear to be favored wherever annual variation in temperature (e.g., temperate deciduous forests, Axelrod 1966) or moisture availability (e.g., tropical deciduous forests, Reich and Borchert 1982, 1984) results in marked favorable vs. unfavorable periods for carbon gain. Evergreen communities dominate regions that are seasonal, are always relatively unfavorable due to low fertility and/or water availability, have short favorable seasons and long unfavorable ones, or have some combination of these or other factors. For example, Waring and Franklin (1979) hypothesized that the combination of warm, but dry, summers and mild, but wet, winters in the Pacific northwest of North America results in a relatively low contrast between favorable (summer) and unfavorable (winter) seasons that favors the evergreen habit. The idea that extended leaf longevity is a nutrient conservation mechanism that enhances nutrient use efficiency and/or long-term carbon gain has also been considered as an explanation for geographical patterns of deciduous vs. evergreen species (e.g., Chapin 1980, Chabot and Hicks 1982).

We recently quantified the relationships between leaf life-span and net photosynthesis, leaf N content, SLA, and other leaf traits for 23 species from adjacent Amazonian forest communities (Reich et al. 1991a). The relationships tended to be nonlinear (best described using log-log equations) and strong ( $r^{2}$ ranged from 0.5 to 0.9). Coley (1988) correlated height growth, defenses, and rates of herbivory with leaf life-span for 41 Panamian tree species and Koike (1988) compared leaf life-span and leaf traits for 30 Japanese deciduous tree species. In this article we ask: how general are relationships of these types, among species from various biomes? Generality of the relationships between leaf lifespan and other leaf, plant, or ecosystem characteristics among an ecologically broad range of species would argue for a common set of adaptive and/or acclimative responses to resource availability, regardless of the modes by which specific resources are limited.

The goals of this study were to evaluate whether:

1) leaf structural, chemical, and physiological traits vary in relation to variation in leaf life-span (and to one another) among diverse species and ecosystems; and if so, how?

2) such relationships derived from diverse ecosystems would be qualitatively and quantitatively consistent with the patterns within a single biome (Amazonia);

3) relative growth rates (RGR) among species from diverse ecosystems are related to variation in leaf lifespan and/or a suite of associated traits (e.g., photosynthetic rate or biomass partitioning); 
4) height growth rates of tree saplings from diverse ecosystems are related to variation in leaf life-span and/or associated traits;

5) forest productivity, production efficiency, biomass allocation, or nutrient conservation of closedcanopy forests are related to variation in leaf life-span, and;

6) based on the answers to questions 1-5 above, assess whether leaf life-span, physiology, chemistry, and/or related factors can serve to conceptually link our understanding of processes at and across the leaf, whole-plant, and ecosystem levels of scale.

To meet these goals, we searched the literature for data on leaf life-spans and corresponding data on leaf structural and physiological traits, plant growth rates, and forest biomass and productivity. Data for several hundred species from tropical, humid temperate, mediterranean, desert, boreal and arctic environments were used in these analyses (Appendix).

\section{Methods}

In searching the literature for data on leaf lifetimes and related traits, first priority was given to studies in which leaf life-span was actively monitored (e.g., Kikuzawa 1983, Shaver 1983, Robertson and Woolhouse 1984). However, studies in which both quantitative leaf demography and physiology or productivity have been measured are relatively infrequent (Nilsen et al. 1987). Therefore, data derived from other means of estimating leaf lifetimes were also used, including estimates based on: (a) initial leaf populations, and numbers produced and dropped between two census dates; (b) seasonal phenological patterns for species that produce and drop all leaves on a plant within short periods; (c) standing foliar biomass and annual litterfall values; and (d) the number of nodes and leaf cohorts for species with known flushing patterns. We evaluated these data to obtain average leaf lifetimes rather than the maximum or apparent retention times sometimes of interest to the authors (e.g., Ewers and Schmid 1981). In no instances did any given study include data on leaf lifespan and all other processes under consideration. Thus, data for a species were often obtained from several different sources. References for data used in these surveys are listed in the Appendix.

Leaf life-span within a species can vary markedly for numerous reasons, but intrinsic variation among species in leaf life-span covers a wider range than variation within species. Within species, leaf lifetime increases with elevation (Ewers and Schmid 1981) or shading (Nilsen et al. 1987, Schoettle 1990), decreases with drought (Reich and Borchert 1984) or chronic air pollution (Reich 1983), and can either increase or decrease with increasing nutrient availability (Turner and Olsen 1976, Reader 1978, Shaver 1983, Lajtha and Whitford 1989) or increasing plant density (Hiroi and Monsi 1966, Bazzaz and Harper 1977). The withinspecies relationship between leaf life-span and nutrient availability appears to differ for natural stands vs. recently fertilized ones, with the latter stands showing increased leaf retention, while higher fertility on natural stands leads to shorter leaf life-span (above citations, plus T. Gower, unpublished data).

Even when growing on similar sites, species show adaptive (i.e., genetic) differences in leaf life-span and related traits (Gower et al. 1992). Since leaf life-span also varies within species due to site quality (i.e., acclimation), and our analyses compare different species on different sites, in this study we cannot separate genotypically fixed vs. phenotypically plastic variation in leaf life-span. However, given the large sample size in the data and the much larger variation in leaf lifespan among than within species, the results of our analyses can be attributed largely to genotypic variation among species.

Data on leaf life-span, gas exchange rates, green and litterfall leaf $\mathrm{N}$, and other traits were compiled for numerous species from diverse ecosystems. Since leaf life-span varies substantially among species, and leaf traits within species vary with leaf age as well, contrasts of gas exchange rates and nutrient concentrations among species were made using leaves of a similar "physiological" age rather than a similar chronological age. Except for litter, we chose the "physiological" age of peak leaf performance as defined by maximum massbased net photosynthetic rate and $\mathrm{N}$ concentration. This "physiological" age corresponds generally with the period when leaf life-span is $\approx 15-25 \%$ over (e.g., Lugg and Sinclair 1981, Hom and Oechel 1983, Reich et al. 1991a). For gas exchange rates, we also restricted our survey to maximum or near-maximum rates observed under field or controlled (e.g., steady-state) conditions at ambient $\mathrm{CO}_{2}$ concentrations.

For comparison of leaf characteristics with data from San Carlos de Rio Negro in Amazonia of Reich et al. (1991a, labelled SCRN data), we label the leaf survey data the LEAVES (leaf life-span among various ecosystems) survey. Where appropriate, comparison with the VINE data set of Field and Mooney (1986) is also made. In analyzing the LEAVES data, results from plants grown in deep shade were often inconsistent with other data with respect to variation of leaf traits visà-vis leaf life-span, especially on a leaf-area basis (this was also true for the SCRN data). Hence, data for shade leaves are not included in the following analyses, unless mentioned otherwise.

To compare growth rates and leaf life-span among species, we chose to survey both relative growth rate (RGR) of seedlings of all life forms from controlled environment studies (labelled GROWTH data), and absolute sapling height growth rates per month (growing season data only) (labelled HEIGHT data). We limited the latter survey to trees, in order to avoid likely confounding in the data if species with prostrate or shrub-like form were used. All growth data were compared to leaf life-span data from field observations. We 
used height growth rates for young trees (in artificial and natural stands) during the approximately linear phase of the sigmoidal growth curve, to minimize age and/or size effects on the data. Height growth and leaf life-span data from Coley (1988) were not included in the HEIGHT survey (1) to avoid placing undue emphasis on any one source of data, and (2) to enable us to qualitatively compare the results of the two independent data sets.

Although relative growth rate (RGR) can be valuable in comparing behavior among species (e.g., Grime and Hunt 1975, Hunt and Lloyd 1987, Shipley and Peters 1990), RGR generally decreases with age and size, thereby making comparison of data from species of different sizes, ages, and life-spans difficult at best. We therefore restricted this survey to studies that report maximum or near-maximum RGR for very young individuals. The merit of comparing these data with field data on leaf life-span is supported by the "scaling" of RGR with height growth for older plants (HEIGHT vs. GROWTH DATA), since relative rankings were similar (data not shown).

To compare stand-level production rates and efficiencies, and biomass partitioning, we used data for woody plants only, from forests and plantations that had achieved a high degree of canopy closure, since changes in annual aboveground net primary production (ANPP, in megagrams per hectare), ratios of foliage to stem dry mass (both in megagrams), and other measures are particularly large during early stand development (Cannell 1985). In addition, mixed-species stands were used only if there was a dominant canopy species, or if co-dominant species had similar leaf lifespan (e.g., mixed spruce-fir or oak-hickory forests). For this survey (labelled STAND) we used data on ANPP, leaf area index, and foliar biomass, and calculated "production efficiency" (Waring 1983) as ANPP per leaf area or biomass. Where appropriate, we compared the STAND data with data of Gower et al. (1992) from southwestern Wisconsin in which adjacent plantation stands of five species with different leaf life-spans were studied. Data on organismal life-span were also compiled for trees.

We compared several different indices of nutrient use efficiency in relation to leaf life-span. These indices include proportional and absolute $\mathrm{N}$ retranslocation (as reported by the authors, or estimated from data on green leaf and fresh leaf litter $\mathrm{N}$ concentrations, adjusted for SLA changes whenever possible); $A_{\text {leaf N }}(A$ expressed per unit leaf $\mathrm{N}$ ), often used as an index of potential photosynthetic $\mathrm{N}$ use efficiency, PPNUE, (Field and Mooney 1986); and leaf litterfall biomass/ litterfall $\mathrm{N}$ concentration (litterfall-NUE), often used as an index of stand-level nutrient use efficiency (Vitousek 1982).

The data sets were all "species based." In statistical analyses and the plotted data, individual data points generally represent a single species within a single stand, using data averaged from a single publication (or several reports if they studied the same site). Multiple data points never represent the same species in the same stand (as would occur if values for different leaves or plants were used). If a paper presented data for a species in two distinct stands (e.g., on different sites or of different age), these data were usually included separately in the data set. Also, when data were reported for a given species in different biomes these were treated separately.

Data were analyzed using regression analyses and separate slopes analyses (SAS 1985). Because a simple linear regression model was not generally appropriate to describe the relations between leaf life-span and leaf, plant and stand measures, we faced two choices: either use a more appropriate general model (or models) or transform the data so that a linear model was appropriate for the transformed data (Neter and Wasserman 1974). Although a series of more complex nonlinear models was fitted to each relationship, no single model yielded the best fit overall, and error variance was often not constant. Therefore, we chose systematically to use logarithmic (base 10) transformations of the data where needed in order to linearize the regression functions and stabilize the error term variances. Also, log transformations are often suitable for biological data and have been previously used in relationship to leaf lifetime in several other studies (e.g., Coley 1988, Williams et al. 1989, Reich et al. 1991a).

For most relationships examined in this study (e.g., height growth rate vs. leaf life-span) it was necessary to $\log$ transform both variables to linearize the regression. For the three graphs in Fig. 1, use of both nontransformed (main compartments) and transformed (inserts) axes allows the reader to examine both the raw and transformed data. We statistically compared relationships between the SCRN and LEAVES data sets using linear contrasts of the transformed variables (SAS 1985). We used this technique to test the hypothesis that different equations describe these relationships for the different data sets. Statistical contrasts were not made between the STAND data and WISCONSIN data (Gower et al. 1992), given the relatively small sample size in the latter.

The inverse of leaf life-span (i.e., an indication of turnover rate), which has been proposed as a conceptually useful correlate of leaf traits (Mooney and Gulmon 1982), was also linearly correlated with a number of leaf traits in this study. However, in comparison with logarithmic transformations, inverse transformations (1/leaf life-span) yielded data sets with unstable error variances and with highly uneven distributions of data (most data compressed in the region of low values) such that the few data points with highest values (very short leaf life-spans) had an inordinate influence on the regression equations. These statistical trends thus support the use of logarithmic rather than inverse functions in these analyses. 

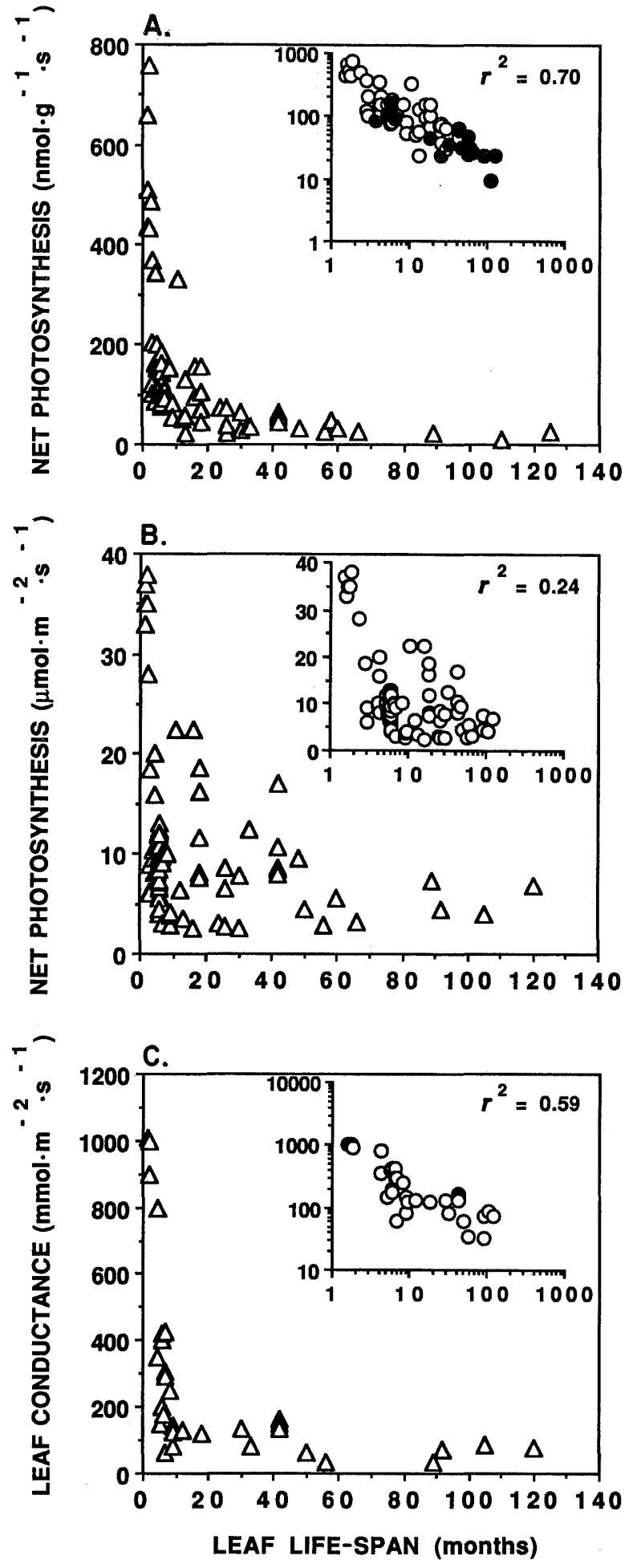

FIG. 1. (A) Maximum mass-based net photosynthetic rate in relation to leaf life-span for species from diverse ecosystems. The insert shows both variables on a $\log$ (base 10) scale; and in this insert only, broad-leaved $(O)$ and needle-leaved (O) data are shown separately (some of the former data are obscured). (B) Maximum area-based net photosynthetic rate in relation to leaf life-span. The insert shows the independent variable on a $\log$ (base 10) scale. (C) Maximum leaf diffusive conductance to water vapor in relation to leaf life-span. The insert shows both variables on a $\log$ (base 10) scale. Regression equations are given in Table 1. All data from LEAVES data set. In this figure only, data are shown on absolute scales for perspective. 
TABLE 1. Summary of relationships between leaf traits and leaf life-span from the LEAVES and SCRN (Reich et al. 1991a) data sets.* For contrasts of adjacent regression equations, those followed by the same superscript letter are not significantly different $(P<.05)$ in either slope or intercept, otherwise both slope and intercept are different.

\begin{tabular}{|c|c|c|}
\hline Data set & Relationship $\dagger$ & $r^{2}$ \\
\hline $\begin{array}{l}\text { LEAVES } \\
\text { SCRN }\end{array}$ & $\begin{array}{l}\log \left(A_{\text {mass }}\right)=2.64-0.64 \log (\text { life-span })^{\mathrm{a}} \\
\log \left(A_{\text {mass }}\right)=2.67-0.65 \log (\text { life-span })^{\mathrm{a}}\end{array}$ & $\begin{array}{l}0.70 \\
0.91\end{array}$ \\
\hline $\begin{array}{l}\text { LEAVES/BROAD } \\
\text { LEAVES/NEEDLE }\end{array}$ & $\begin{array}{l}\log \left(A_{\text {mass }}\right)=2.58-0.60 \log (\text { life-span })^{\mathrm{a}} \\
\log \left(A_{\text {mass }}\right)=2.43-0.56 \log (\text { life-span })^{\mathrm{a}}\end{array}$ & $\begin{array}{l}0.52 \\
0.78\end{array}$ \\
\hline $\begin{array}{l}\text { LEAVES } \\
\text { SCRN }\end{array}$ & $\begin{array}{l}\log \left(\text { leaf } N_{\text {mass }}\right)=1.61-0.31 \log (\text { life-span })^{\mathrm{a}} \\
\log \left(\text { leaf } \mathrm{N}_{\text {mass }}\right)=1.53-0.30 \log (\text { life-span })^{\mathrm{a}}\end{array}$ & $\begin{array}{l}0.52 \\
0.52\end{array}$ \\
\hline $\begin{array}{l}\text { LEAVES/BROAD } \\
\text { LEAVES/NEEDLE }\end{array}$ & $\begin{array}{l}\log \left(\text { leaf } \mathrm{N}_{\text {mass }}\right)=1.62-0.33 \log (\text { life-span })^{\mathrm{a}} \\
\log \left(\text { leaf } \mathrm{N}_{\text {mass }}\right)=1.52-0.26 \log (\text { life-span })^{\mathrm{a}}\end{array}$ & $\begin{array}{l}0.41 \\
0.67\end{array}$ \\
\hline $\begin{array}{l}\text { LEAVES } \\
\text { SCRN }\end{array}$ & $\begin{array}{l}\text { leaf } \mathrm{N}_{\text {area }} \text { as a function of life-span } \\
\text { leaf } \mathrm{N}_{\text {area }} \text { as a function of life-span }\end{array}$ & $\begin{array}{l}\text { NS } \\
\text { NS }\end{array}$ \\
\hline $\begin{array}{l}\text { LEAVES } \\
\text { SCRN }\end{array}$ & $\begin{array}{l}\log (\text { SLA })=2.44-0.43 \log (\text { life-span })^{\mathrm{a}} \\
\log (\text { SLA })=2.37-0.33 \log (\text { life-span })^{\mathrm{a}}\end{array}$ & $\begin{array}{l}0.54 \\
0.78\end{array}$ \\
\hline $\begin{array}{l}\text { LEAVES/BROAD } \\
\text { LEAVES/NEEDLE }\end{array}$ & $\begin{array}{l}\log (\text { SLA })=2.41-0.38 \log (\text { life-span })^{\mathrm{a}} \\
\log (\text { SLA })=2.29-0.40 \log (\text { life-span })^{\mathrm{a}}\end{array}$ & $\begin{array}{l}0.44 \\
0.62\end{array}$ \\
\hline $\begin{array}{l}\text { LEAVES } \ddagger \\
\text { SCRN }\end{array}$ & $\begin{array}{l}A_{\text {area }}=19.4-8.6 \log (\text { life-span })^{\mathrm{a}} \\
A_{\text {area }}=17.6-7.3 \log (\text { life-span })^{\mathrm{a}}\end{array}$ & $\begin{array}{l}0.24 \\
0.75\end{array}$ \\
\hline $\begin{array}{l}\text { LEAVES } \\
\text { SCRN }\end{array}$ & $\begin{array}{l}\log \left(A_{\text {leaf } N}\right)=2.08-0.38 \log (\text { life-span })^{\mathrm{a}} \\
\log \left(A_{\text {leaf } \mathrm{N}}\right)=2.29-0.36 \log (\text { life-span })^{\mathrm{a}}\end{array}$ & $\begin{array}{l}0.37 \\
0.79\end{array}$ \\
\hline $\begin{array}{l}\text { LEAVES } \\
\text { SCRN }\end{array}$ & $\begin{array}{l}\log (\text { life-span PPNUE })=2.06+0.64 \log (\text { life-span })^{\mathrm{a}} \\
\log (\text { life-span PPNUE })=2.29+0.64 \log (\text { life-span })^{\mathrm{a}}\end{array}$ & $\begin{array}{l}0.65 \\
0.93\end{array}$ \\
\hline $\begin{array}{l}\text { LEAVES } \\
\text { SCRN }\end{array}$ & $\begin{array}{l}\log (g)=2.82-0.53 \log (\text { life-span })^{\mathrm{a}} \\
\log (g)=3.38-0.54 \log (\text { life-span })^{\mathrm{a}}\end{array}$ & $\begin{array}{l}0.59 \\
0.74\end{array}$ \\
\hline
\end{tabular}

* Relationships were significant at $P<.01$ (if $r^{2}$ is given), or not significant (NS), unless noted otherwise. Where necessary to compare data sets, SCRN and LEAVES data were transformed similarly. Comparison of broad-leaved (LEAVES/BROAD) and needle-leaved (LEAVES/NEEDLE) species were made for subsets of the LEAVES data set.

† Log (base 10); units: $\mathrm{N}_{\text {mass }}(\mathrm{mg} / \mathrm{g}) ;$ life-span (months); $\mathrm{N}_{\text {area }}\left(\mathrm{g} / \mathrm{m}^{2}\right) ; \mathrm{SLA}\left(\mathrm{cm}^{2} / \mathrm{g}\right) ; A_{\text {mass }}\left(\mathrm{nmol} \cdot \mathrm{g}^{-1} \cdot \mathrm{s}^{-1}\right) ; A_{\text {area }}\left(\mu \mathrm{mol} \cdot \mathrm{m}^{-2} \cdot \mathrm{s}^{-1}\right)$; $A_{\text {leaf N }}\left(\mu \mathrm{mol} \cdot \mathrm{mol}^{-1} \cdot \mathrm{s}^{-1}\right) ; g\left(\mathrm{H}_{2} \mathrm{O}, \mathrm{mmol} \cdot \mathrm{m}^{-2} \cdot \mathrm{s}^{-1}\right)$; life-span PPNUE (index of potential maximum life-span photosynthetic nitrogen use efficiency based on $A_{\text {leaf N }}$ leaf life-span).

† This relationship was significant at $P<.05$. Note added in proof: The $\log -\log$ form of this relationship is $\log A_{\text {area }}=1.22$ $-0.29 \log \left(\right.$ life-span); $\quad r^{2}=0.23$.

0.52 ) from $>65 \mathrm{mg} / \mathrm{g}$ to $<10 \mathrm{mg} / \mathrm{g}$ with increasing leaf life-span (Fig. 2A). The regression relationships between leaf $\mathrm{N}_{\text {mass }}$ and life-span were similar for broadleaved and needle-leaved groups (Table 1). Leaf $\mathrm{N}_{\text {area }}$ was not significantly correlated with leaf life-span (Fig. 2B) using either the complete data or any subset (e.g., broad-leaved species, needle-leaved species, leaf lifespan $\leq 13 \mathrm{mo}$ ).

Specific leaf area (SLA, leaf area per unit leaf mass) decreased significantly $\left(P<.001, r^{2}=0.54\right)$ from 400 to $40 \mathrm{~cm}^{2} / \mathrm{g}$ as leaf life-span varied from $6 \mathrm{wk}$ to $8 \mathrm{yr}$ (Fig. 2C). This relationship did not differ significantly between broad-leaved and needle-leaved species (Table 1). Both $\mathrm{N}_{\text {mass }}$ (Fig. 2D) and $A_{\text {mass }}$ (Fig. 3A) were significantly correlated with SLA $\left(P<.001, r^{2}=0.54\right.$ and 0.48 , respectively). $A_{\text {mass }}$ was a linear function of $\mathrm{N}_{\text {mass }}$ (Fig. 3B) $\left(P<.001, r^{2}=0.74\right)$, while $A_{\text {area }}$ was not significantly related to $\mathrm{N}_{\text {area }}$ (Fig. $3 \mathrm{C}$ ). The results presented above suggest that as a general phenomenon, photosynthetic rate declines in relation to increasing leaf life-span, largely as a result of parallel decreases in leaf $\mathrm{N}_{\text {mass }}$ and SLA.

Are these data from diverse ecosystems consistent with patterns observed in a single Amazonian system (SCRN data set, Reich et al. 1991a)? In general, the same transformations (most often log-log) were required in the two data sets to linearize the data (suggesting similar overall forms). $A_{\text {mass }}$ was the leaf trait most highly correlated with leaf life-span in both data sets. The slopes and intercepts of this $\log -\log$ relationship were nearly identical in these two independent data sets (Table 1), suggesting that this relationship is fundamental in nature, and closely approximated by this equation. The relationships between leaf $\mathrm{N}_{\text {mass }}$, leaf diffusive conductance, and $A_{\text {leafN }}$ vs. leaf life-span were also similar in the LEAVES and SCRN data sets (Table 1), while leaf $N_{\text {area }}$ was not related to leaf life-span in either survey, or when both surveys were combined (data not shown). A scatterplot of data for woody species from the Iberian peninsula (del Arco et al. 1991, and not included in the LEAVES survey) also shows a similar pattern of leaf $\mathrm{N}_{\text {mass }}$ in relationship to leaf lifespan as observed in the LEAVES and SCRN data.

For the LEAVES data the slope of the SLA-leaf lifespan relationship was steeper (but not significantly different) than for SCRN data (Table 1). When the two data sets were combined, a significant correlation $\left(r^{2}\right.$ $=0.58$ ) was observed between the transformed variables and the slope was intermediate (data not shown). In the LEAVES survey, leaf life-span explained only 

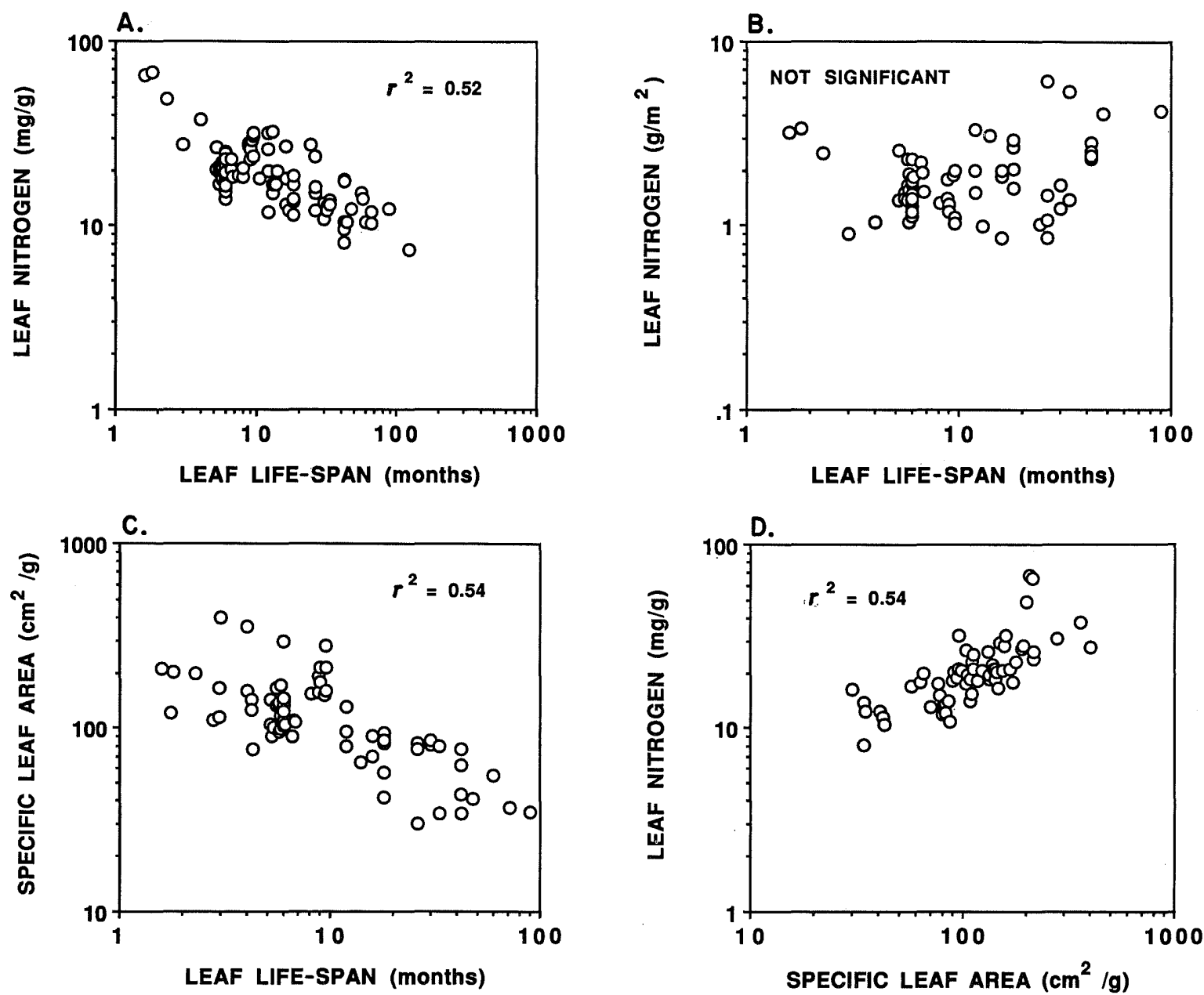

FIG. 2. (A) Mass-based leaf $N$ concentration in relation to leaf life-span for species from diverse ecosystems. (B) Area-based leaf $\mathrm{N}$ in relation to leaf life-span. (C) Specific leaf area in relation to leaf life-span. (D) Leaf $\mathrm{N}_{\text {mass }}$ in relation to SLA. Regression equations are given in Tables 1 and 2. All data from LEAVES data set.

$24 \%\left(P<.05, r^{2}=0.24\right)$ of the variation in $A_{\text {area }}$, and variation around the slope of the regression equation was greater for leaves of short rather than long leaf lifetimes, violating the assumptions of the regression model. Nonetheless, the regression equation for the $A_{\text {area }}-$ leaf life-span relationship in the LEAVES survey is relatively similar to that based on the SCRN data (Table 1). Significant positive relationships for $\mathrm{N}_{\text {mass }}$ vs. SLA and $A_{\text {mass }}$ vs. SLA were found in both the LEAVES and SCRN data sets, but the slopes were significantly greater in the latter data (Table 2).

The mass-based photosynthesis- $\mathrm{N}$ relationship in the LEAVES survey had a regression equation similar to those in both the SCRN (Reich et al. 1991a) and VINE (Field and Mooney 1986) data (Table 2), and all three correlations were strong $\left(r^{2}\right.$ between 0.74 and 0.85 ). The lack of a significant $A_{\text {area }}$ vs. $\mathrm{N}_{\text {area }}$ relation in the LEAVES data was consistent with a similar lack of significant relationship in the SCRN data (Table 2, or when both data sets were combined [data not shown]), and with a significant but weak relationship $\left(r^{2}=0.28\right)$ in the VINE data.

\section{Growth rate and other whole-plant traits}

RGR of seedlings varied by over an order of magnitude among species and decreased $\left(P<.001, r^{2}=\right.$ 0.61 ) with increasing leaf life-span (Fig. 4A). Similar to relations between life-span and other leaf traits, this relationship was best described using $\log$-log transformations. Neither root mass ratio ${ }^{2}$ (in grams of root per gram whole plant) nor leaf mass ratio (in grams of leaf per gram whole plant) was significantly correlated with leaf life-span (Table 3). In contrast, leaf area ratio (LAR; in square centimetres of leaf area per gram whole plant) was highly correlated with leaf life-span $\left(r^{2}=0.89\right)$, being much higher in species with short- than longlived leaves (Fig. 4B and Table 3).

Several indices have been suggested as potential determinants of RGR. Were any of these correlated with

\footnotetext{
${ }^{2}$ Root mass ratio and leaf mass ratio are often referred to in the literature as root weight ratio (RWR) and leaf weight ratio (LWR).
} 

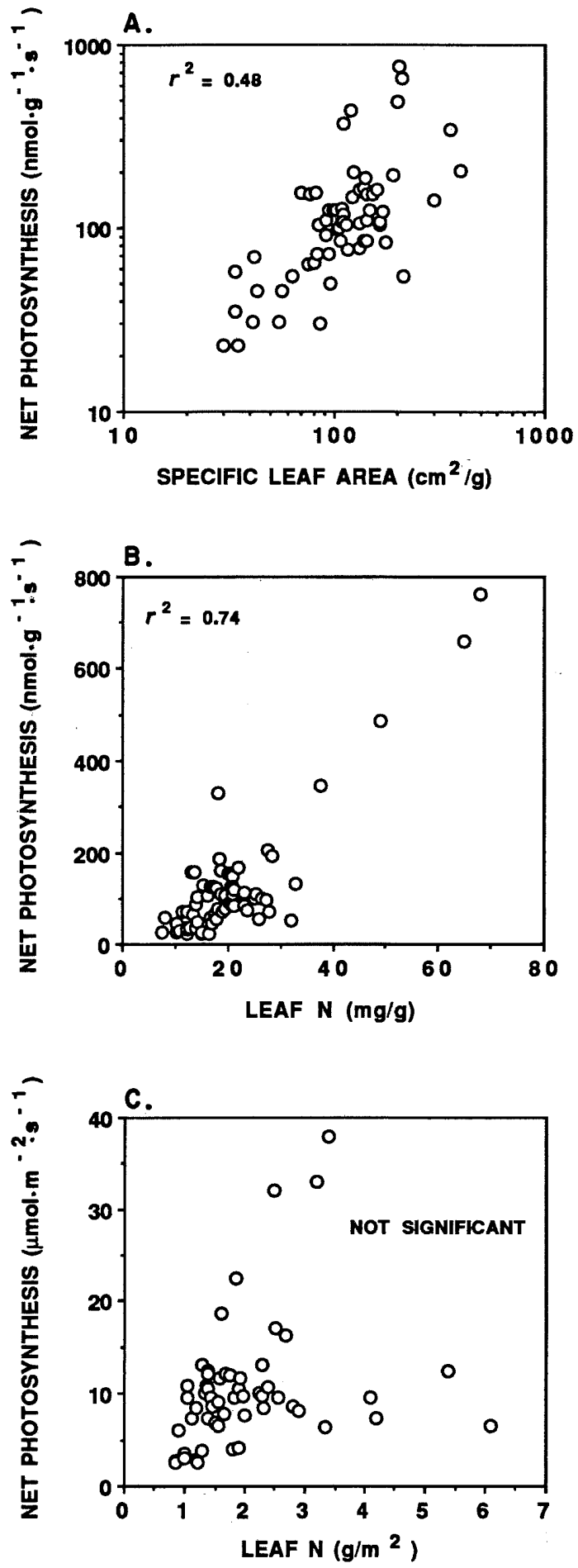

Fig. 3. (A) Mass-based net photosynthetic rates in relation to specific leaf area. (B)-(C) Relationships between net photosynthesis and leaf $\mathrm{N}$ concentrations on (B) mass and (C) area bases. Regression equations are given in Table 2. All data from LEAVES data set.
RGR? LAR $\left(r^{2}=0.68\right)$, SLA $\left(r^{2}=0.68\right)$, leaf $\mathrm{N}_{\text {mass }}$ $\left(r^{2}=0.67\right), A_{\text {mass }}\left(r^{2}=0.55\right)$, and leaf mass ratio $\left(r^{2}=\right.$ $0.49)$ were all positively related $(P<.001)$ with RGR, while root mass ratio $\left(r^{2}=0.64\right)$ was negatively related to RGR (Fig. 5 and Table 3). The relationship between LAR and RGR was similar (Table 3) to a relationship found for an independent data set (Poorter and Remkes 1990). The above results suggest that RGR decreases with increasing leaf life-span largely as a result of parallel decreases in $A_{\text {mass }}$ and LAR with increasing lifespan, given the potential control of RGR by the combination of $A_{\text {mass }}$ and LAR.

Height growth rates of saplings varied 30-fold among species and were strongly correlated with leaf life-span (Fig. 6A). Similar to $A_{\text {mass }}$ and RGR, absolute height growth rate declined rapidly with increasing leaf lifespan up to 10 mo and declined gradually with further increases, and the relationship was linear on a log-log scale $\left(P<.001, r^{2}=0.72\right)$. A similar relationship between height growth and leaf life-span was observed for trees in a tropical wet forest (Coley 1988, data not included in LEAVES). In the LEAVES survey, height growth rate was linearly correlated $(P<.001)$ with $A_{\text {mass }}\left(r^{2}=0.78\right), A_{\text {area }}\left(r^{2}=0.53\right)$, SLA $\left(r^{2}=0.54\right)$ and $\mathrm{N}_{\text {mass }}\left(r^{2}=0.37\right.$ ) (Fig. 6 and Table 3 ). Height growth rate was not significantly correlated with leaf $\mathrm{N}_{\text {area }}(P$ $>.25, r^{2}=0.01$ ), and data were not available to test relationships between height growth and biomass partitioning coefficients.

Trees with long leaf life-span also tend to live longer than those with shorter leaf life-span, but this trend is not general among all sites. Using data available on tree life-spans (e.g., Waring and Franklin 1979, Uhl 1987, Loehle 1988) leaf and tree life-span were correlated $(P<.05)$ over a broad gradient (approximately two orders of magnitude variation in tree life-span), but the relationship was very weak $\left(r^{2}=0.19\right)$ and extremely variable. It is interesting that strong relationships between leaf life-span, plant growth (this paper), and defenses (Coley 1988) parallel similar, but weaker, relations among tree life-span, growth, and defenses (Loehle 1988).

\section{Stand-level processes}

In closed-canopy forest stands, foliage mass (per unit ground area) increased sharply with increasing leaf lifespan $\left(P<.001, r^{2}=0.74\right)$ (Table 4 and Fig. 7). Total leaf area per unit ground area (leaf area index, LAI) also increased with leaf life-span, but the two parameters were weakly correlated $\left(P<.05, r^{2}=0.27\right)$ (Table 4 ), as a result of offsetting trends in total foliage mass (increasing) and SLA (decreasing) in relation to leaf life-span. Foliage mass as a proportion of total biomass $\left(r^{2}=0.64\right)$ or of aboveground biomass $\left(r^{2}=0.61\right)$ was positively related $(P<.001)$ to leaf life-span (Table 4). These latter results were somewhat surprising, since within species the ratio of foliage mass : stem mass is 
TABLE 2. Summary of relationships between leaf structural, chemical, and physiological characteristics for the LEAVES and SCRN (Reich et al. 1991a) data sets, including comparison with the VINE data set (Field and Mooney 1986) in two cases.* For contrasts of adjacent regression equations, those followed by the same superscript letter are not significantly different $(P<.05)$ in either slope or intercept, otherwise both slope and intercept are different. Units are as in Table 1.

\begin{tabular}{|c|c|c|}
\hline Data set & Relationship & $r^{2}$ \\
\hline $\begin{array}{l}\text { LEAVES } \\
\text { SCRN }\end{array}$ & $\begin{array}{l}\log \left(\text { leaf } \mathrm{N}_{\text {mass }}\right)=0.22+0.53 \log (\mathrm{SLA})^{\mathrm{a}} \\
\log \left(\text { leaf } \mathrm{N}_{\text {mass }}\right)=-0.57+0.87 \log (\mathrm{SLA})^{\mathrm{b}}\end{array}$ & $\begin{array}{l}0.54 \\
0.63\end{array}$ \\
\hline $\begin{array}{l}\text { LEAVES } \\
\text { SCRN }\end{array}$ & $\begin{array}{l}\log \left(A_{\text {mass }}\right)=0.15+0.93 \log (\mathrm{SLA})^{\mathrm{a}} \\
\log \left(A_{\text {mass }}\right)=-1.32+1.62 \log (\mathrm{SLA})^{\mathrm{b}}\end{array}$ & $\begin{array}{l}0.48 \\
0.77\end{array}$ \\
\hline $\begin{array}{l}\text { LEAVES } \\
\text { SCRN } \\
\text { VINE }\end{array}$ & $\begin{array}{l}A_{\text {mass }}=-95.2+10.9\left(\mathrm{~N}_{\text {mass }}\right)^{\mathrm{a}} \\
A_{\text {mass }}=-92.5+12.2\left(\mathrm{~N}_{\text {mass }}\right)^{\mathrm{a}} \\
A_{\text {mass }}=-76.1+10.6\left(\mathrm{~N}_{\text {mass }}\right)^{2}\end{array}$ & $\begin{array}{l}0.74 \\
0.85 \\
0.85\end{array}$ \\
\hline $\begin{array}{l}\text { LEAVES (all data) } \\
\text { SCRN (all data) } \\
\text { VINE (all data) }\end{array}$ & $\begin{array}{l}\left(A_{\text {area }}\right) \text { as a function of }\left(\mathrm{N}_{\text {area }}\right) \\
\left(A_{\text {area }}\right) \text { as a function of }\left(\mathrm{N}_{\text {area }}\right) \\
A_{\text {area }}=0.3+5.7\left(\mathrm{~N}_{\text {area }}\right)\end{array}$ & $\begin{array}{l}\text { NS } \\
\text { NS } \\
0.28\end{array}$ \\
\hline $\begin{array}{l}\text { LEAVES (life-span } \leq 1 \mathrm{yr} \text { ) } \\
\text { LEAVES (life-span }>1 \mathrm{yr} \text { ) } \\
\text { SCRN (life-span } \leq 1 \mathrm{yr} \text { ) } \\
\text { SCRN (life-span }>1 \mathrm{yr} \text { ) }\end{array}$ & $\begin{array}{l}A_{\text {area }}=-1.8+7.41\left(\mathrm{~N}_{\text {area }}\right) \\
\left(A_{\text {area }}\right) \text { as a function of }\left(\mathrm{N}_{\text {area }}\right) \\
\left(A_{\text {area }}\right) \text { as a function of }\left(\mathrm{N}_{\text {area }}\right) \\
A_{\text {area }}=4.1+1.28\left(\mathrm{~N}_{\text {area }}\right)\end{array}$ & $\begin{array}{l}0.40 \\
\text { NS } \\
\text { NS } \\
0.31\end{array}$ \\
\hline $\begin{array}{l}\text { LEAVES (all data) } \\
\text { SCRN (all data) }\end{array}$ & $\begin{array}{l}\left(\mathrm{N}_{\text {area }}\right) \text { vs. }\left(\mathrm{N}_{\text {mass }}\right) \\
\left(\mathrm{N}_{\text {area }}\right) \text { vs. }\left(\mathrm{N}_{\text {mass }}\right)\end{array}$ & $\begin{array}{l}\text { NS } \\
\text { NS }\end{array}$ \\
\hline $\begin{array}{l}\text { LEAVES (life-span } \leq 1 \mathrm{yr} \text { ) } \\
\text { LEAVES (life-span }>1 \mathrm{yr} \text { ) } \\
\text { SCRN (life-span } \leq 1 \mathrm{yr}) \\
\text { SCRN (life-span }>1 \mathrm{yr} \text { ) }\end{array}$ & $\begin{array}{l}\mathrm{N}_{\text {area }}=0.86+0.034\left(\mathrm{~N}_{\text {mass }}\right) \\
\left(\mathrm{N}_{\text {area }}\right) \text { vs. }\left(\mathrm{N}_{\text {mass }}\right) \\
\left(\mathrm{N}_{\text {area }}\right) \text { vs. }\left(\mathrm{N}_{\text {mass }}\right) \\
\mathrm{N}_{\text {area }}=0.11+0.13\left(\mathrm{~N}_{\text {mass }}\right)\end{array}$ & $\begin{array}{l}0.41 \\
\text { NS } \\
\text { NS } \\
0.86\end{array}$ \\
\hline $\begin{array}{l}\text { LEAVES } \dagger \\
\text { SCRN }\end{array}$ & $\begin{array}{l}A_{\text {leaf N }}=-40+49 \log (\mathrm{SLA})^{\mathrm{a}} \\
A_{\text {leaf N }}=-236+160 \log (\mathrm{SLA})^{\mathrm{b}}\end{array}$ & $\begin{array}{l}0.19 \\
0.62\end{array}$ \\
\hline $\begin{array}{l}\text { LEAVES } \\
\text { SCRN }\end{array}$ & $\begin{array}{l}A_{\text {leaf N }} \text { as a function of }\left(\mathrm{N}_{\text {mass }}\right) \\
A_{\text {leaf N }}=38.2+2.63\left(\mathrm{~N}_{\text {mass }}\right)\end{array}$ & $\begin{array}{l}\text { NS } \\
0.39\end{array}$ \\
\hline $\begin{array}{l}\text { LEAVES } \\
\text { SCRN }\end{array}$ & $\begin{array}{l}A_{\text {leaf N }} \text { as a function of }\left(\mathrm{N}_{\text {area }}\right) \\
A_{\text {leaf N }} \text { as a function of }\left(\mathrm{N}_{\text {area }}\right)\end{array}$ & $\begin{array}{l}\text { NS } \\
\text { NS }\end{array}$ \\
\hline
\end{tabular}

* Relationships were significant at $P<.01$, or not significant (NS), unless noted otherwise. Where necessary to compare data sets, SCRN and LEAVES data were transformed similarly.

$\dagger$ This relationship was significant at $P<.05$.

sensitive to stand age (woody mass continues to increase once foliage mass reaches a steady state), which could confound the leaf life-span-based relationship among species. Neither total biomass, aboveground biomass, nor root biomass was well correlated with leaf life-span. There was also no apparent relationship between proportional root mass (root: total biomass) and leaf life-span; however, caution must be taken in interpreting the data involving root mass, since few appropriate data are available and their accuracy is questionable (Vogt et al. 1986).

Annual aboveground net primary production (ANPP) of forest stands was not significantly correlated with leaf life-span (or total foliage mass or LAI) using all data pooled (Fig. 7B, Table 4, and data not shown). For conifers with leaf life-span $>1 \mathrm{yr}$, however, ANPP decreased significantly $\left(P<.001, r^{2}=0.48\right)$ with increasing leaf life-span. Both $A_{\text {mass }}$ and SLA decreased $\left(P<.001, r^{2}=0.83\right.$ and 0.61 , respectively) in relation to increasing foliage mass (Table 4) (no trend was found for $A_{\text {area }}$ ). For all data pooled, production efficiency of forest canopies on a mass basis (ANPP/foliage biomass) decreased with increasing leaf life-span $(P<$ $\left..001, r^{2}=0.78\right)$ and varied by almost an order of magnitude from highest values for species with short-lived leaves to lowest values in forests with long-lived foliage (Table 4 and Fig. 7C). ANPP/foliage biomass was positively related to both $\mathrm{A}_{\text {mass }}\left(r^{2}=0.71\right)$ and SLA $\left(r^{2}=\right.$ $0.57)$ (Table 4). These data suggest that the accumulation of foliage mass characteristic of species with longlived foliage compensates for their low $A_{\text {mass }}, \mathrm{N}_{\text {mass }}$, and SLA, resulting in the lack of relationship between ANPP and leaf life-span. The data also suggest that broad-scale variation in ANPP is a function of foliage biomass multiplied by photosynthetic rate. Production efficiency on a unit leaf area basis (ANPP/LAI) was not significantly correlated with leaf life-span or $A_{\text {area }}$.

ANPP was not related to any measure of biomass distribution. Production efficiency on a mass basis, ANPP/foliage biomass, was negatively related to the proportion of mass in foliage (either as a share of aboveground or of total biomass; $P<.001, r^{2}=0.55$ and 0.64 , respectively) (Table 4). Forests with short leaf life-spans (high foliage turnover rates) had both a lower total amount and proportion of total biomass in foliage and a higher efficiency of use of such foliage. 


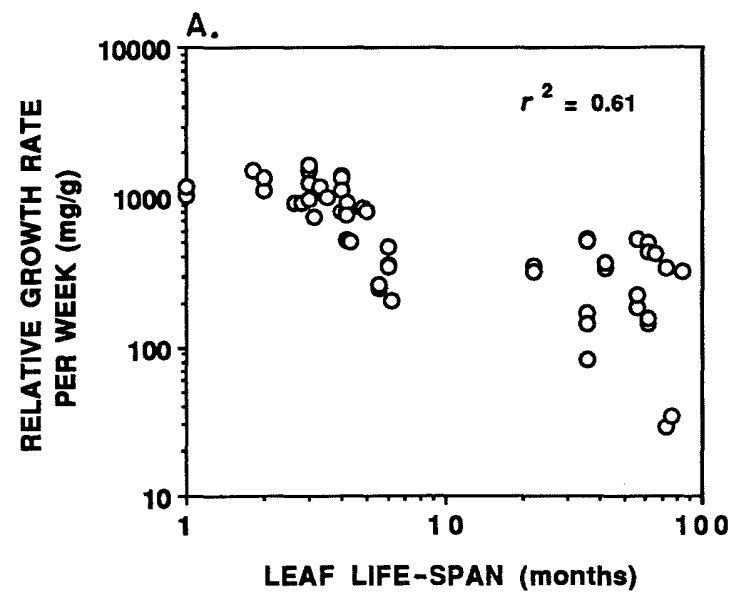

STAND data and WISCONSIN data of Gower et al. (1992) for five adjacent plantation stands (Table 4). In both data sets, total foliage mass and LAI increased similarly with leaf life-span, while mass-based production efficiency (ANPP/foliage mass) decreased. However, area-based canopy production efficiency (ANPP/LAI) was strongly correlated with leaf life-span among the five species studied by Gower et al. (1992), but was not significantly related to leaf life-span in this survey. In the STAND and WISCONSIN data sets $A_{\text {mass }}$ and SLA both decrease in relation to total foliage mass, but are positively related with mass-based production efficiency (ANPP/foliage mass) (Table 4).

\section{Nitrogen use efficiency}

There was no significant relationship between proportional $\mathrm{N}$ retranslocation and either leaf life-span or leaf $\mathrm{N}_{\text {mass }}$ (Fig. 8B and Table 5). Since species with short-lived leaves have greater leaf $\mathrm{N}_{\text {mass }}$ (Fig. 2) and proportional retranslocation did not vary in relation to leaf life-span or $\mathrm{N}_{\text {mass }}$, it follows that absolute $\mathrm{N}$ retranslocation and litterfall $\mathrm{N}_{\text {mass }}$ should decrease with increasing leaf life-span or decreasing leaf $\mathrm{N}_{\text {mass }}$. Litterfall-based NUE (sensu Vitousek 1982, defined as the inverse of litterfall $\mathrm{N}_{\text {mass }}$ ) was weakly positively related $\left(P<.01, r^{2}=0.27\right)$ to leaf life-span (Fig. 8A and Table 5), but was not significantly related $(P>$ $\left..05, r^{2}=0.17\right)$ if the two data points for species with shortest leaf life-spans are omitted from the data set. Absolute $\mathrm{N}$ retranslocation was correlated $(P<.001$, $\left.r^{2}=0.57\right)$ with leaf life-span: species with short-lived leaves retranslocate a greater amount per unit leaf mass than species with long-lived leaves (Fig. 8C). As expected, both absolute $\mathrm{N}$ retranslocation and litterfall NUE were better correlated with $\mathrm{N}_{\text {mass }}$ than with leaf life-span (Table 5). The slope of the close relationship between absolute $\mathrm{N}$ retranslocation and leaf $\mathrm{N}_{\text {mass }}\left(r^{2}\right.$ $=0.89$, with an intercept near zero) suggests that on average most species retranslocate $\approx 55-60 \%$ of their leaf $\mathrm{N}$ prior to leaf shedding.

Relating leaf life-span to indices of soil $\mathrm{N}$ availability is difficult because of great variation in methodology among researchers and a wide variety of time periods used for such studies. Using soil data from 13 forest stands in Wisconsin and Massachusetts (data from Aber et al. 1985), we observed that leaf life-span was greater as annual net $\mathrm{N}$ mineralization (considered an index on $\mathrm{N}$ availability) decreased $\left(P<.01, r^{2}=0.61\right.$, Table 4). However, in a replicated study of five tree species growing in 28-yr-old plantations on a common site, Son (1991) found no relationship between annual net $\mathrm{N}$ mineralization and leaf life-span. These two contrasting findings suggest that the relationship between leaf life-span and $\mathrm{N}$ availability results from different leaf life-spans enhancing plant success on soils of varying $\mathrm{N}$ availability, and secondarily from the impacts of leaf life-span on $\mathrm{N}$ availability. 
TABLE 3. Summary of relationships between growth rate, partitioning, and leaf life-span from the GROWTH and HEIGHT data sets, plus the relationship between RGR and LAR from Poorter and Remkes (1990), labeled HERBS. All relationships were significant at $P<.01$.

\begin{tabular}{|c|c|c|}
\hline Data set & Relationship* & $r^{2}$ \\
\hline GROWTH & $\log (\mathrm{RGR})=3.19-0.51 \log ($ life-span $)$ & 0.61 \\
\hline GROWTH & $\log (\mathrm{LAR})=2.54-0.64 \log ($ life-span $)$ & 0.89 \\
\hline GROWTH & leaf mass ratio as a function of life-span & NS \\
\hline GROWTH & root mass ratio as a function of life-span & NS \\
\hline GROWTH & $\log (\mathrm{RGR})=3.43-1.64 \log ($ root mass ratio $)$ & 0.64 \\
\hline GROWTH & $\log (\mathrm{RGR})=1.07+0.80 \log (\mathrm{LAR})$ & 0.68 \\
\hline HERBS & $\log (\mathrm{RGR})=1.35+0.78 \log (\mathrm{LAR})$ & 0.67 \\
\hline GROWTH & $\log (\mathrm{RGR})=1.77+1.79 \log ($ leaf mass ratio $)$ & 0.49 \\
\hline GROWTH & $\log (\mathrm{RGR})=0.79+1.38 \log \left(\right.$ leaf $\left.\mathrm{N}_{\text {mass }}\right)$ & 0.67 \\
\hline GROWTH & $\log (\mathrm{RGR})=0.78+0.86 \log \left(A_{\text {mass }}\right)$ & 0.55 \\
\hline GROWTH & $\log (\mathrm{RGR})=-1.21+1.62 \log (\mathrm{SLA})$ & 0.68 \\
\hline GROWTH & $\log \left(A_{\text {mass }}\right)=0.49+0.81 \log (\mathrm{LAR})$ & 0.84 \\
\hline GROWTH & $\log \left(A_{\text {mass }}\right)=2.85+2.41 \log ($ leaf mass ratio $)$ & 0.64 \\
\hline GROWTH & $\log (\mathrm{LAR})=-1.56+1.52 \log (\mathrm{SLA})$ & 0.76 \\
\hline HEIGHT & $\log ($ height growth $)=1.61-0.66 \log ($ life-span $)$ & 0.72 \\
\hline HEIGHT & height growth $=0.07+0.10$ (leaf $\left.A_{\text {mass }}\right)$ & 0.78 \\
\hline HEIGHT & height growth $=-5.56+1.82\left(\right.$ leaf $\left.A_{\text {area }}\right)$ & 0.53 \\
\hline HEIGHT & $\log ($ height growth $)=-1.04+1.03 \log ($ SLA $)$ & 0.54 \\
\hline
\end{tabular}

* Log (base 10); units: RGR (mg $\left.\cdot \mathrm{g}^{-1} \cdot \mathrm{wk}^{-1}\right)$; life-span (months); LAR (leaf area ratio = leaf area/total plant mass) (cm $\left./ \mathrm{g}\right)$; root mass ratio $=$ root mass/total plant mass; leaf mass ratio = leaf biomass $/$ total plant biomass; height growth $(\mathrm{cm} / \mathrm{mo}) ;$ other units as in Table 1.

\section{DISCUSSION}

Do the data presented in this paper support current hypotheses about species variation in physiological, life history, successional, and other traits? Do these data represent universal relationships across species and biomes, and/or across levels of hierarchical scales?
We address these issues below, building from an initial discussion focused at the leaf scale to considerations of whole-plant, stand, and ecological issues. We also model these relationships conceptually (Fig. 9), showing linkages at leaf, whole-plant, and stand levels.

The data analyses in this study depend on correla-

TABLE 4. Summary of relationships between stand-level carbon dynamics and leaf life-span from the STAND data set. All relationships were significant at $P<.01$, unless noted NS (not significant, $P>.05$ ). Comparisons are also made with data from Gower et al. (1992) (WISCONSIN data) where appropriate.

\begin{tabular}{|c|c|c|}
\hline Data set & Relationship* & $r^{2}$ \\
\hline STAND & $\log ($ foliage mass $)=0.09+0.54 \log ($ life-span $)$ & 0.74 \\
\hline WISCONSIN & $\log ($ foliage mass $)=0.13+0.68 \log ($ life-span $)$ & 0.95 \\
\hline STAND $†$ & $\log (\mathrm{LAI})=0.46+0.24 \log ($ life-span $)$ & 0.27 \\
\hline WISCONSIN & $\log (\mathrm{LAI})=0.43+0.28 \log ($ life-span $)$ & 0.80 \\
\hline STAND & ANPP as a function of life-span & NS \\
\hline WISCONSIN & ANPP as a function of life-span & NS \\
\hline STAND & $\log (\mathrm{ANPP} /$ foliage mass $)=0.98-0.60 \log ($ life-span $)$ & 0.78 \\
\hline WISCONSIN & $\log (\mathrm{ANPP} /$ foliage mass $)=0.91-0.67 \log ($ life-span $)$ & 0.95 \\
\hline STAND & ANPP/LAI as a function of life-span & NS \\
\hline STAND & $\log ($ foliage $:$ total mass $)=-2.20+0.54 \log ($ life-span $)$ & 0.64 \\
\hline STAND & $\log ($ foliage $:$ above mass $)=-2.07+0.47 \log ($ life-span $)$ & 0.61 \\
\hline STAND & $A_{\text {mass }}=210-138.2 \log ($ foliage mass $)$ & 0.83 \\
\hline WISCONSIN & $A_{\text {mass }}=177-106.9 \log ($ foliage mass $)$ & 0.80 \\
\hline STAND & $\log ($ SLA $)=2.29-0.39 \log ($ foliage mass $)$ & 0.61 \\
\hline WISCONSIN & $\log (\mathrm{SLA})=2.41-0.64 \log ($ foliage mass $)$ & 0.96 \\
\hline STAND & $\mathrm{ANPP} /$ foliage mass $=0.27+0.0205\left(A_{\text {mass }}\right)$ & 0.71 \\
\hline WISCONSIN & $\mathrm{ANPP} /$ foliage mass $=-0.18+0.0226\left(A_{\text {mass }}\right)$ & 0.78 \\
\hline STAND & $\log (\mathrm{ANPP} /$ foliage mass $)=-2.46+1.36 \log$ (SLA) & 0.57 \\
\hline WISCONSIN & $\log (\mathrm{ANPP} /$ foliage mass $)=-2.72+1.53 \log (\mathrm{SLA})$ & 0.99 \\
\hline STAND & $\log (\mathrm{ANPP} /$ foliage mass $)=0.63-0.0051$ (foliage mass) & 0.72 \\
\hline STAND & $\log (\mathrm{ANPP} / \mathrm{LAI})=0.734-0.0074(\mathrm{LAI})$ & 0.64 \\
\hline STAND & $\log (\mathrm{ANPP} /$ foliage mass $)=-1.07-0.77 \log ($ foliage $:$ total mass $)$ & 0.64 \\
\hline STAND & $\log (\mathrm{ANPP} /$ foliage mass $)=-0.99-0.77 \log ($ foliage $:$ aboveground mass $)$ & 0.55 \\
\hline
\end{tabular}

* Foliage mass is total foliage dry mass per unit ground area $(\mathrm{Mg} / \mathrm{ha})$; ANPP is aboveground net primary production $\left(\mathrm{Mg} \cdot \mathrm{ha}^{-1} \cdot \mathrm{yr}^{-1}\right)$; foliage : total mass and foliage : aboveground mass are the ratios of total foliage mass to total biomass and aboveground biomass, respectively; LAI is leaf area index $\left(\mathrm{m}^{2} / \mathrm{m}^{2}\right)$; other units as in Table 1 .

$\dagger$ This relationship was significant at $P<.05$. 

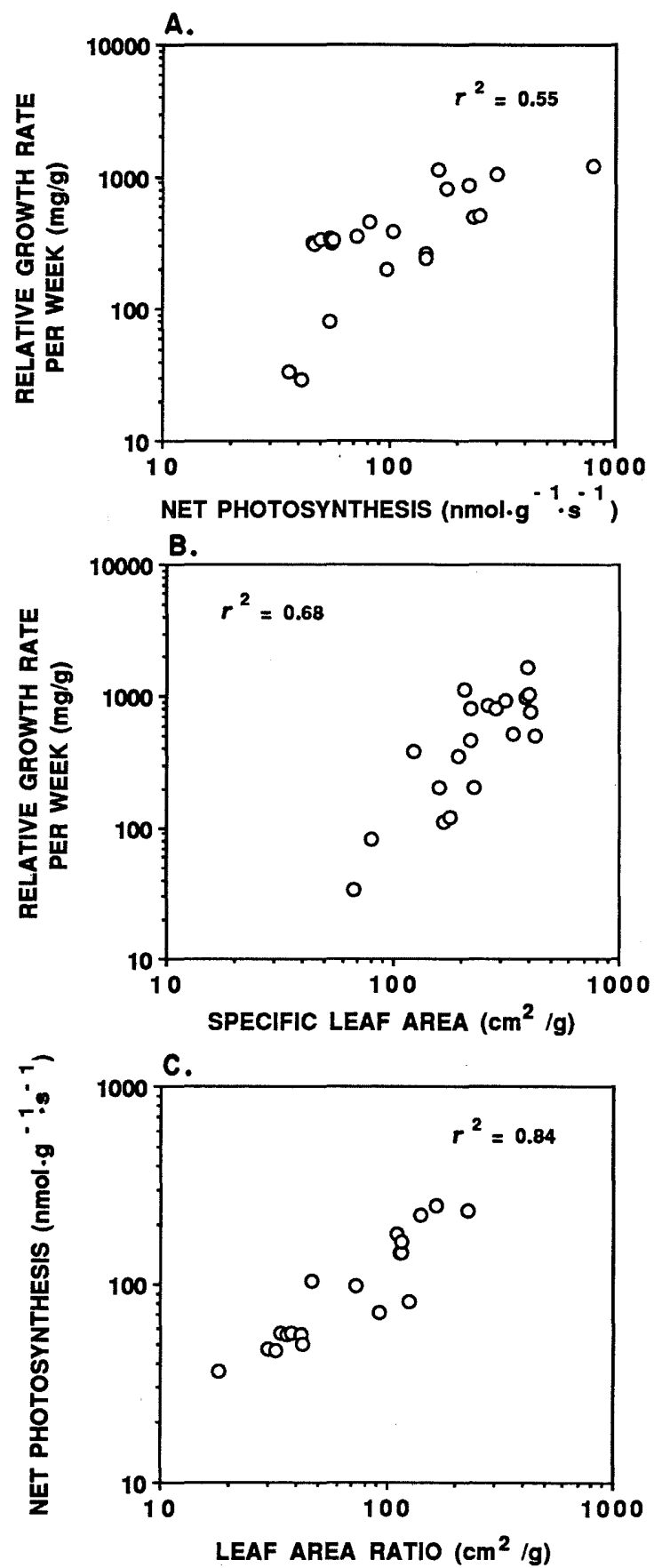

FIG. 5. (A) and (B) Relative growth rate (RGR) per week of seedlings in relation to mass-based net photosynthetic rate and specific leaf area, respectively. (C) Net photosynthesis in relation to leaf area ratio. Regression equations are given in Table 3. All data from GROWTH data set.

tion, similar to previous attempts to find a quantitative basis for making broad ecological inferences (Vitousek 1982, Field and Mooney 1986, Lloyd and Hunt 1987, Reich 1987, Raich and Nadelhoffer 1989). However, most of the specific relationships examined in this paper have been demonstrated or hypothesized to be causal, either directly or indirectly. For example, several questions have direct mechanistic roots (e.g., does variation in $A_{\text {mass }}$ in relation to leaf life-span reflect parallel variation in leaf N?). Other issues involve the role of mutually supporting traits in influencing processes at the next higher level of scale (e.g., does high $A_{\text {mass }}$ and LAR enable species with short leaf life-spans to have high RGR?), or of offsetting traits (e.g., does the accumulation of great foliage mass by species with long-lived foliage increase stand-level ANPP and NUE and compensate for negative impacts of low $A_{\text {mass }}, \mathrm{N}_{\text {mass }}$, $A_{\text {leaf N }}$, and SLA?). Thus, the strength and generality of the correlations serve as quantitative evidence supporting or conflicting with process-based theory, and can serve in conceptual (Fig. 9) or quantitative model development.

\section{Leaf scale}

Consistent relationships in two independent data sets (LEAVES and SCRN) suggest that the relationships among leaflife-span and $\mathrm{N}_{\text {mass }}, \mathrm{SLA}$, and leaf $A_{\text {mass }}$ (and to a lesser extent $A_{\text {area }}$ and $A_{\text {leaf N }}$ ) across species are fundamental in nature, with forms approximated by the equations in Table 1 . In contrast, the data indicate that there are no general relationships between leaflifespan and either leaf $\mathrm{N}_{\text {area }}$ or proportional $\mathrm{N}$ retranslocation from senescing foliage.

Relationships between leaf traits and life-span were generally weaker for the LEAVES than SCRN sets (Tables 1 and 2). It is not surprising that species from adjacent communities with similar climate might display less unexplained variation with respect to leaf lifespan and associated traits than more widely dispersed species from diverse biomes. Moreover, the fact that the latter species were studied by numerous investigators using nonstandardized protocol likely contributes to the amount of unexplained variation.

Taken together, these data demonstrate that species with short leaf life-spans generally have thin (high SLA) leaves with high mass-based $\mathrm{N}$ concentrations and high photosynthetic rates, with the reverse true for species with long-lived leaves, supporting widely held but largely unquantified postulates (e.g., Chabot and Hicks 1982, Mooney and Gulmon 1982). Short-lived leaves are also physically less tough (Coley 1988, Reich et al. $1991 a$ ) and tend to have lesser amounts of secondary chemical defenses (Coley 1988). These traits, in combination with greater leaf $\mathrm{N}_{\text {mass }}$, are probably responsible for the greater rates of herbivory short-lived leaves experience in comparison with long-lived leaves (Coley 1988). On theoretical grounds, certain leaf traits, such as greater investment in secondary compounds and physically resistant structures, are considered to be essential for enabling leaves to achieve extended longevity, and should also reduce photosynthetic capacity by diluting the proportion of leaf tissue allocated to photosynthetic machinery and enzymes (Mooney and Gulmon 1982, Coley et al. 1985, Field and Mooney 1986). 
The data presented in this paper, together with that of Coley (1988) and the SCRN data (Reich et al. 1991a), provide strong supporting evidence for such hypotheses.

Absolute changes in leaf traits with increasing lifespan were greatest among species with the shortest lifespans and least among species with life-spans $>1$ or 2 yr. As suggested previously (Reich et al. 1991a), small differences in leaf duration for species with short leaf life-spans may have important physiological and ecological ramifications, whereas the converse, that large differences in leaf duration for leaves with long leaf life-spans are relatively unimportant, is not necessarily true. Although physiological performance among longlived leaves of varying life-spans might be only slightly different, differences in leaf life-span might have important impacts on foliage accumulation, stand nutrient cycling or use efficiency, and net carbon gain or nutrient use efficiency over the leaf life-span (Gosz 1981, Aerts 1990).

There is ongoing debate as to whether extended leaf longevity requires greater initial construction costs (usually expressed per gram of leaf tissue) and evidence to date has been mixed (e.g., Merino et al. 1982, 1984, Gower et al. 1989, Williams et al. 1989). Greater concentrations of lignin, phenolics, and/or other secondary metabolites in long-lived leaves would require greater synthetic costs, but these may be partially offset by the lower costs incurred by long-lived leaves due to low $\mathrm{N}$ concentrations. If construction costs are expressed on a leaf area basis, however, there is clearly a greater cost for long-lived leaves, since these generally require 200$1000 \%$ greater dry mass per unit area than short-lived leaves (Fig. 2). Although construction costs are usually not considered on an area basis, we argue that this is the appropriate basis for comparison with other measures expressed on an area basis, and that SLA by itself is a useful area-based index of construction cost (and is inversely related to cost).

Mass-based net photosynthetic rate is the leaf trait most highly correlated with leaf life-span in both the LEAVES $\left(r^{2}=0.70\right)$ and SCRN $\left(r^{2}=0.91\right)$ data sets, and the two regression equations are almost identical. These relationships are well described by log-log equations, and they also approximate inverse functions $\left(r^{2}\right.$ $=0.68$ and 0.98 , respectively), as predicted previously (Mooney and Gulmon 1982) but not empirically demonstrated. The decline in $A_{\text {mass }}$ with increasing leaf lifespan is probably a result of parallel decreases in leaf $\mathrm{N}_{\text {mass }}$ and SLA; the role of $\mathrm{N}_{\text {mass }}$ in regulating $A_{\text {mass }}$ is well known (Field and Mooney 1986), but in addition, even for a given $\mathrm{N}_{\text {mass }}$, decreasing SLA results in lower $A_{\text {mass }}$ (Reich et al. 1991a).

Similarity in the $A_{\text {mass }}$ to $\mathrm{N}_{\text {mass }}$ relationship in three independent data sets (Table 2) supports the idea that this is a universal relationship among species (see Field and Mooney 1986, Reich et al. 1991a). In contrast to the strong relationships between leaf life-span and mass-
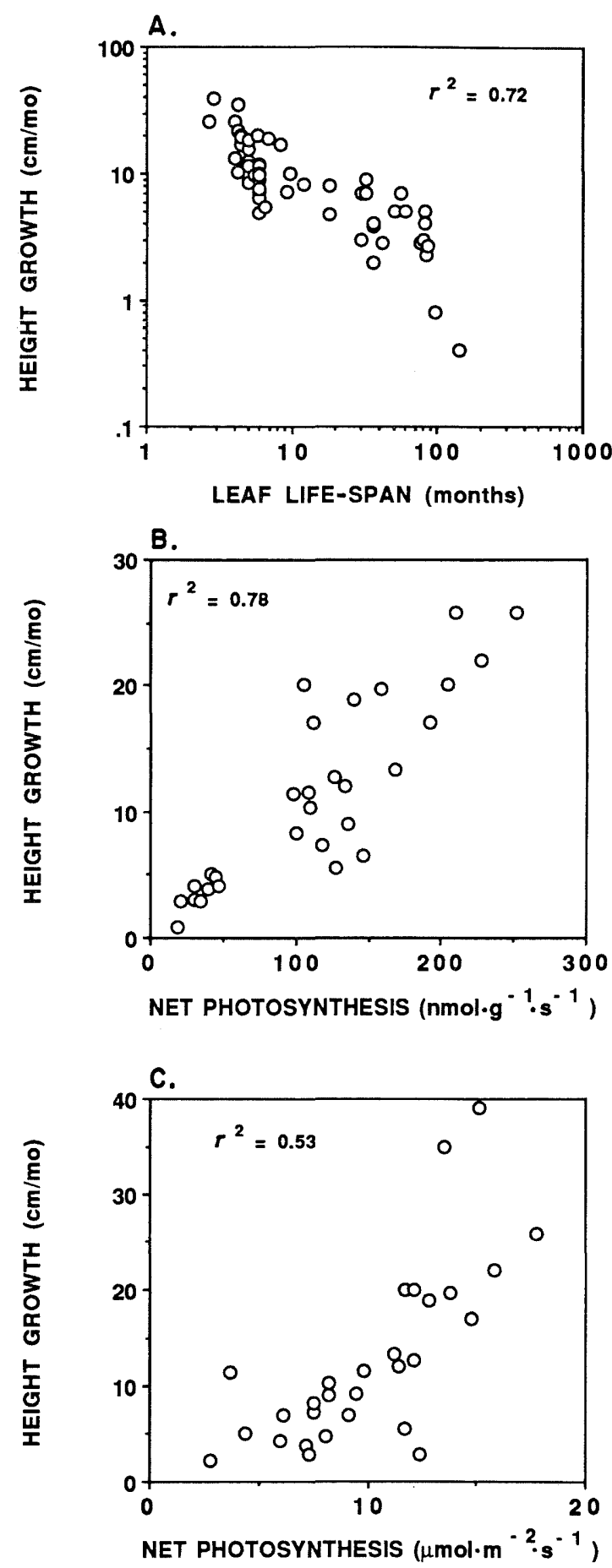

FIG. 6. Height growth rate of tree saplings in relation to (A) leaf life-span; (B) mass-based net photosynthetic rate; and (C) area-based net photosynthetic rate. Regression equations are given in Table 3. All data from HEIGHT data set. Height growth rate expressed per growing season month.

based photosynthesis and $\mathrm{N}$ in both surveys, relationships among leaf life-span, $A_{\text {area }}$, and $\mathrm{N}_{\text {area }}$ were weak and variable. The lack of interdependence of leaf $\mathrm{N}_{\text {area }}$ and leaf life-span is partially the result of offsetting 

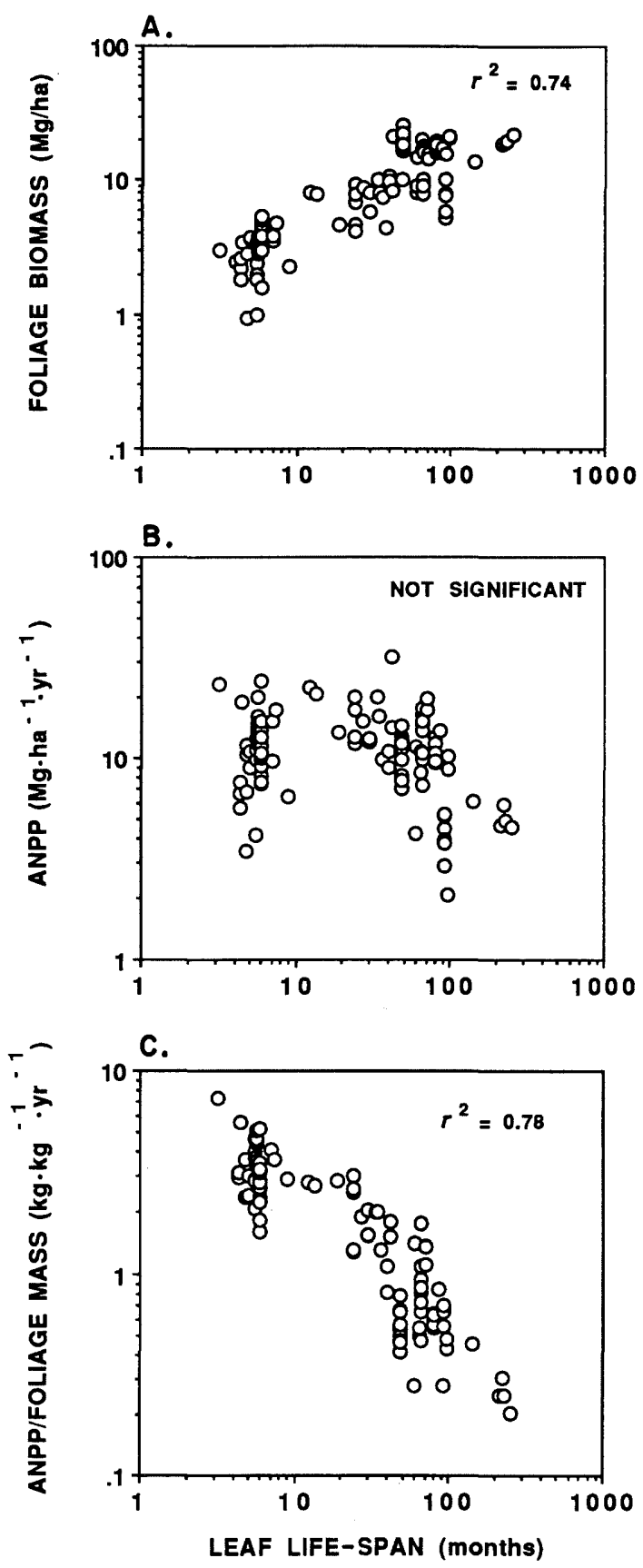

FIG. 7. (A) Total foliage biomass per unit ground area in relation to leaf life-span for diverse forest stands. (B) Annual aboveground net primary production (ANPP) in relation to leaf life-span. (C) Production efficiency (ANPP/foliage biomass) in relation to leaf life-span. Regression equations are given in Table 4. All data from STAND data set.

influences on $\mathrm{N}_{\text {area }}$ of SLA and $\mathrm{N}_{\text {mass }}$ as they change with leaf lifetime: parallel decreases in SLA (which increases leaf mass/area) and $\mathrm{N}_{\text {mass }}$ result in no net change in $\mathrm{N}_{\text {area }}$ on average. Furthermore, in both the LEAVES and SCRN surveys, decreasing $A_{\text {area }}$ with increasing leaf life-span was unrelated to the allocation of $\mathrm{N}$ per unit leaf area (since $\mathrm{N}_{\text {area }}$ was not significantly related to either leaf life-span or $A_{\text {area }}$ ). Apparently, $A_{\text {area }}$ decreases with leaf life-span due to decreasing $A_{\text {leaf N }}$ associated with increasing leaf thickness (decreasing SLA) (Field and Mooney 1986, Reich et al. 1991a).

Variation in $A_{\text {area }}$ among species was weakly correlated with leaf $\mathrm{N}_{\text {area }}$ in the VINE data, but not in the SCRN or LEAVES data (Table 2). Thus, the weak or nonsignificant nature of this relationship among the three data sets suggests that there is not a fundamental $A_{\text {area }}$-to- $\mathrm{N}_{\text {area }}$ relationship among species. This may be partially ascribed to offsetting relationships: $A_{\text {mass }}$ scales linearly with $\mathrm{N}_{\text {mass }}$, and although $\mathrm{N}_{\text {mass }}$ decreases with decreasing SLA, decreasing SLA increases $\mathrm{N}_{\text {area }}$ for any given $\mathrm{N}_{\text {mass }}$. This results in the potential for leaves to have similar $\mathrm{N}_{\text {area }}$ but different $\mathrm{N}_{\text {mass }}$. At a given $\mathrm{N}_{\text {area }}$, leaves with higher $\mathrm{N}_{\text {mass }}$ realize a higher $A_{\text {area }}$ than leaves with lower $\mathrm{N}_{\text {mass }}$, due to the positive relationship between $A_{\text {mass }}$ and $\mathrm{N}_{\text {mass }}$, giving rise to considerable scatter in the $A_{\text {area }}-\mathrm{N}_{\text {area }}$ relationship.

Moreover, the LEAVES data includes two distinct groups of species with high leaf $\mathrm{N}_{\text {area }}$ : (1) sclerophylls (including conifers) with low $\mathrm{N}_{\text {mass }}$ but very low SLA, that in combination result in high leaf $\mathrm{N}_{\text {area }}$ (because of their low $\mathrm{N}_{\text {mass }}$ such species have low $A_{\text {mass }}$, but somewhat higher $A_{\text {area }}$ (due to low SLA), and (2) herbaceous and woody pioneer and other species with high $\mathrm{N}_{\text {mass }}$ and SLA, that together result in high leaf $\mathrm{N}_{\text {area }}$. Given their high $\mathrm{N}_{\text {mass }}$, these species have high $A_{\text {mass }}$ and $A_{\text {area }}$. Division of the LEAVES data set into species with leaf life-spans $<1$ vs. $>1$ yr supports this idea. The subset made up of leaves with shorter life-spans included all the data points with high $\mathrm{N}_{\text {area }}$ and $A_{\text {area }}$ (plus others with low values of each), and there was a significant $\left(P<.01, r^{2}=0.40\right)$ correlation of $A_{\text {area }}$ to $\mathrm{N}_{\text {area }}$, roughly similar in slope to the VINE data set (Table 2). The subset with longer lived leaves included all the data points with high $\mathrm{N}_{\text {area }}$ but low $A_{\text {area }}$, as well as other points with low values for each.

Leaf life-span and photosynthetic rate in relation to plant growth rate.-Although this paper has focused on leaf life-span as an "ecological integrator" of plant processes, leaf life-span is one of several interrelated and mutually supporting traits, and cannot be viewed in isolation. Another of these traits is photosynthetic capacity. Instantaneous photosynthetic rate has frequently been cited as a poor correlate of growth rate or productivity (e.g., Dornhoff and Shibles 1970, Fisher et al. 1981, Briggs et al. 1986) and has had limited ability to explain growth differences among genotypes or species. However, most such studies focused on a narrow range of plants, often within a species, and most previous attempts to correlate instantaneous photosynthetic capacity with longer term indices of growth or production used area-based photosynthetic rates only. As shown in this paper, area-based rates are less well related with leaf life-span and other leaf and wholeplant traits than mass-based rates. In our surveys we found strong correlations between $A_{\text {mass }}$ and leaf lifespan, leaf $\mathrm{N}_{\text {mass }}, \mathrm{RGR}$, height growth rate, and canopy 
production efficiency. Poorter et al. (1990) and M. B. Walters et al. (unpublished data) also found strong correlations between $A_{\text {mass }}$ and RGR among species. $A_{\text {mass }}$ appears to be at least correlated with processes at the leaf, plant, and stand level, but we suggest that these relationships are causal (Fig. 9), especially if we consider $A_{\text {mass }}$ as one of a suite of interrelated traits possessed by each species.

\section{Higher levels of integration: plant and stand scale}

How do the leaf-scale patterns discussed above fit conceptually with the available data and hypotheses relative to whole-plant or stand-level function? The results of this paper indicate that greater $A_{\text {mass }}, \mathrm{N}_{\text {mass }}$, SLA, seedling LAR and RGR, sapling height growth rate, and production efficiency of forest canopies are all strongly related to shorter leaf life-span and to each other (Tables 1-4, Figs. 1-7). In species with short leaf life-spans, greater rates of photosynthesis coupled with high proportional allocation to foliage area (LAR) result in high RGR and height growth for young plants (Table 3, Figs. 4-6). In contrast, in forest stands, species with short leaf life-spans have greater rates of photosynthesis (and therefore greater production efficiency), but these are coupled with a low standing proportion of biomass in foliage, with the result that ANPP is not different than in species with longer leaf life-spans (Table 4 and Fig. 7). The relationship between leaf lifespan and proportional foliage mass (foliage/total biomass) differs between young, individual plants (no relationship) and mature, closed-canopy stands (an increase with increasing leaf life-span). This does not necessarily reflect a change in allocation with increasing size and density; more likely it reflects the time required for species with long-lived foliage to accumulate foliage mass. As a result, trends among species apparent for young plants grown in relative isolation differ from those of older forest stands, and these will be discussed separately.

Plant level. - There has been considerable discussion about whether allocation to roots vs. shoots should be related to RGR. Tilman (1988) argued that allocation of biomass to any nonphotosynthetic tissue should lessen RGR, but the broadest evidence available to date does not strongly support that argument. Studies of 132 and 68 species, respectively, by Hunt and Lloyd (1987) and Shipley and Peters (1990), found no indication that greater proportional allocation of biomass to leaves resulted in higher RGR. However, Poorter and Remkes (1990) found a weak correlation $\left(r^{2}=\right.$ 0.26 ) between RGR and leaf mass ratio for 24 species (data recalculated by the authors), and in the GROWTH data, RGR was positively related to leaf mass ratio $\left(r^{2}=0.49\right)$. Korner (1991) suggests there may be several combinations of partitioning regimes, respiratory and photosynthetic rates, architecture, and tissue longevities that can result in a given RGR, or confer success
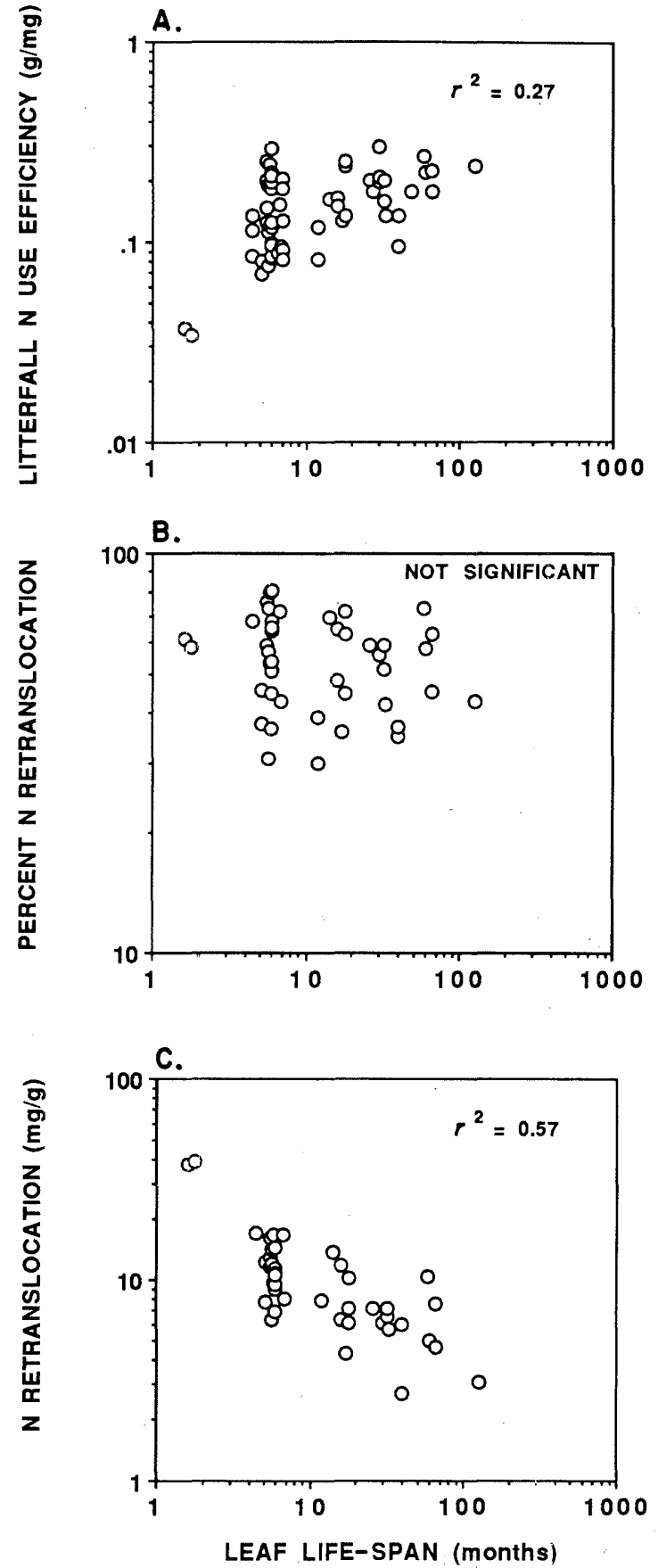

FIG. 8. Litterfall $\mathrm{N}$ use efficiency (A), percent $\mathrm{N}$ retranslocation (B), and absolute $\mathrm{N}$ retranslocation (C) in relation to leaf life-span for diverse species. Regression equations are given in Table 5. All data from NITROGEN data set.

in a given habitat. Nonetheless, it is informative to examine the relation of individual factors to RGR and one another, and perhaps necessary before we can understand their complex interactions.

More consistent among data sets with several or more species is the generally strong relationship between LAR and RGR: we found a strong correlation in this study 
TABLE 5. Summary of relationships between nitrogen dynamics and leaf life-span from the NITROGEN data set. All relationships were significant at $P<.01$, unless noted NS (not significant, $P>.05$ ).

\begin{tabular}{|c|c|c|}
\hline Data set & Relationship* & $r^{2}$ \\
\hline NITROGEN & $\% \mathrm{~N}$ retranslocation as a function of leaf life-span & NS \\
\hline NITROGEN & $\% \mathrm{~N}$ retranslocation as a function of leaf $\mathrm{N}_{\text {mass }}$ & NS \\
\hline NITROGEN & $\log ($ absolute $N$ retranslocation $)=1.38-0.40 \log ($ life-span $)$ & 0.57 \\
\hline NITROGEN & absolute $\mathrm{N}$ retranslocation $=-0.30+0.585\left(\right.$ leaf $\left.\mathrm{N}_{\text {mass }}\right)$ & 0.89 \\
\hline NITROGEN & $\log ($ litterfall NUE $)=-1.11+0.26 \log ($ life-span $)$ & 0.27 \\
\hline NITROGEN & $\log ($ litterfall NUE $)=0.38-1.01 \log \left(\right.$ leaf $\left.N_{\text {mass }}\right)$ & 0.67 \\
\hline NITROGEN & litterfall NUE $=0.23-0.0012\left(A_{\text {lear N }}\right)$ & 0.26 \\
\hline NITROGEN & litterfall NUE $=-1.16+0.11 \log ($ life-span PPNUE $)$ & 0.36 \\
\hline NITROGEN & $\log ($ soil $N$ mineralization $)=2.34-0.425 \log ($ life-span $)$ & 0.61 \\
\hline
\end{tabular}

* Absolute $\mathrm{N}$ retranslocation $\left(\mathrm{mg} / \mathrm{g}\right.$ leaf); litterfall $\mathrm{NUE}=\left[1 /\left(\right.\right.$ litterfall leaf $\left.\left.\mathrm{N}_{\text {mass }}\right)\right](\mathrm{g} / \mathrm{mg}) ;$ soil $\mathrm{N}$ mineralization $\left(\mathrm{kg} \cdot \mathrm{ha}{ }^{-1}\right.$. $\left.\mathrm{yr}^{-1}\right)$; other units as in Table 1 .

$\left(r^{2}=0.68\right)$, as did Potter and Jones (1977) and Poorter and Remkes (1990), but not Popma and Bongers (1988). In the survey of Poorter and Remkes (1990), the relationship between RGR and LAR ( $r^{2}=0.67$, recalculated by the authors) was similar in slope as for the GROWTH data in the present study (Table 3). However, LAR is poorly correlated with RGR when plants from sun and shade are considered together (Popma and Bongers 1988; M. B. Walters et al., unpublished data).

LAR is mathematically the product of a morphological component (SLA) that is well correlated with leaf life-span, and an allocational component (leaf mass ratio) that is not well correlated with leaf life-span. RGR, LAR, SLA, $\mathrm{N}_{\text {mass }}$, and $A_{\text {mass }}$ are all strongly positively correlated with each other in this paper and in the independent data set of Poorter and colleagues (Poorter and Remkes 1990, Poorter et al. 1990). It is interesting that these five traits are each also strongly correlated with leaf life-span, while traits such as $A_{\text {area }}$, $\mathrm{N}_{\text {area }}$, and leaf mass ratio, that are less well related to RGR, are also poorly related to leaf life-span. We suggest that short leaf life-span and high $A_{\text {mass }}$, SLA, N $\mathrm{N}_{\text {mass }}$, and LAR are a suite of interrelated traits in plants that have high RGR and that in fact enable such plants to grow at an accelerated rate. Preferential dry matter allocation to foliage is not as closely linked with leaf life-span or physiological traits ( $A_{\text {mass }}$, SLA) and although it may be related to RGR in some instances, it does not consistently confer greater RGR.

The relationships among leaf life-span, SLA, LAR, leaf $\mathrm{N}_{\text {mass}}$, photosynthetic capacity, and growth rate, appear to be linked through a complex of whole-plant processes and interactions (see Fig. 9). Within species, individual plants grown in environments with high (vs. low) $\mathrm{N}$ availability have greater leaf $\mathrm{N}_{\text {mass }}$ (e.g., Klinka and Carter 1990, del Arco et al. 1991), resulting in higher $A_{\text {mass }}$ (e.g., Field and Mooney 1986), as well as proportionally greater canopy growth than root growth (e.g., Walters and Reich 1989), which in combination will lead to a greater total canopy carbon gain, high rates of canopy expansion, and high rates of height growth. High rates of canopy expansion and height growth will result in earlier leaf senescence (according to canopy carbon assimilation optimalization theory, see Hirose and Werger 1987, Field 1988), with associated retranslocation of $\mathrm{N}$ to new foliage higher on the stem and with faster turnover rates of individual leaves (i.e., shorter leaf life-span).

Resource-level specialization by species also plays a role in this model (the above paragraph describes plasticity or acclimation). Species adapted to resource-rich environments tend to have shorter leaf life-spans and higher SLA, LAR, and $\mathrm{N}_{\text {mass }}$ in any given environment than other species, which lead to higher $A_{\text {mass }}$ and canopy carbon gain in resource-rich environments. High SLA also maximizes total leaf area per unit leaf biomass and thus light capture. Furthermore, intrinsically shorter leaf life-spans further accelerate the rate of leaf turnover, retranslocation, and production of new leaves (Fig. 9).

If short leaf life-span and high $A_{\text {mass }}, \mathrm{SLA}, \mathrm{N}_{\text {mass }}$, and LAR are so advantageous for carbon balance and growth, on what basis do we attribute the tendency of species towards slow growth, extended leaf life-span, and related traits, as is common in resource-poor habitats? Do such species actually outgrow "faster growing, short leaf life-span" species in resource-poor environments? The evidence suggests that this may be true in some instances, but not as a general rule. Many authors (e.g., Logan 1965a, $b$, Loach 1970) report that "fast-growing/short leaf life-span" species often have higher growth or photosynthetic rates than "slowgrowing/long leaf life-span" species even in resourcepoor environments. A long-held alternative explanation (e.g., Chapin 1980) is that extended leaf longevity and related traits enable individuals to survive in lowresource or stressful habitats long after most or all individuals of "fast-growing/short leaf life-span" species have died. Death can result from a lack of resources (specifically water, nutrients, light, and carbon), and also from "external" agents, such as herbivores, diseases, mechanical damage, desiccation, freezing, etc. Unfortunately, this alternative explanation is difficult 


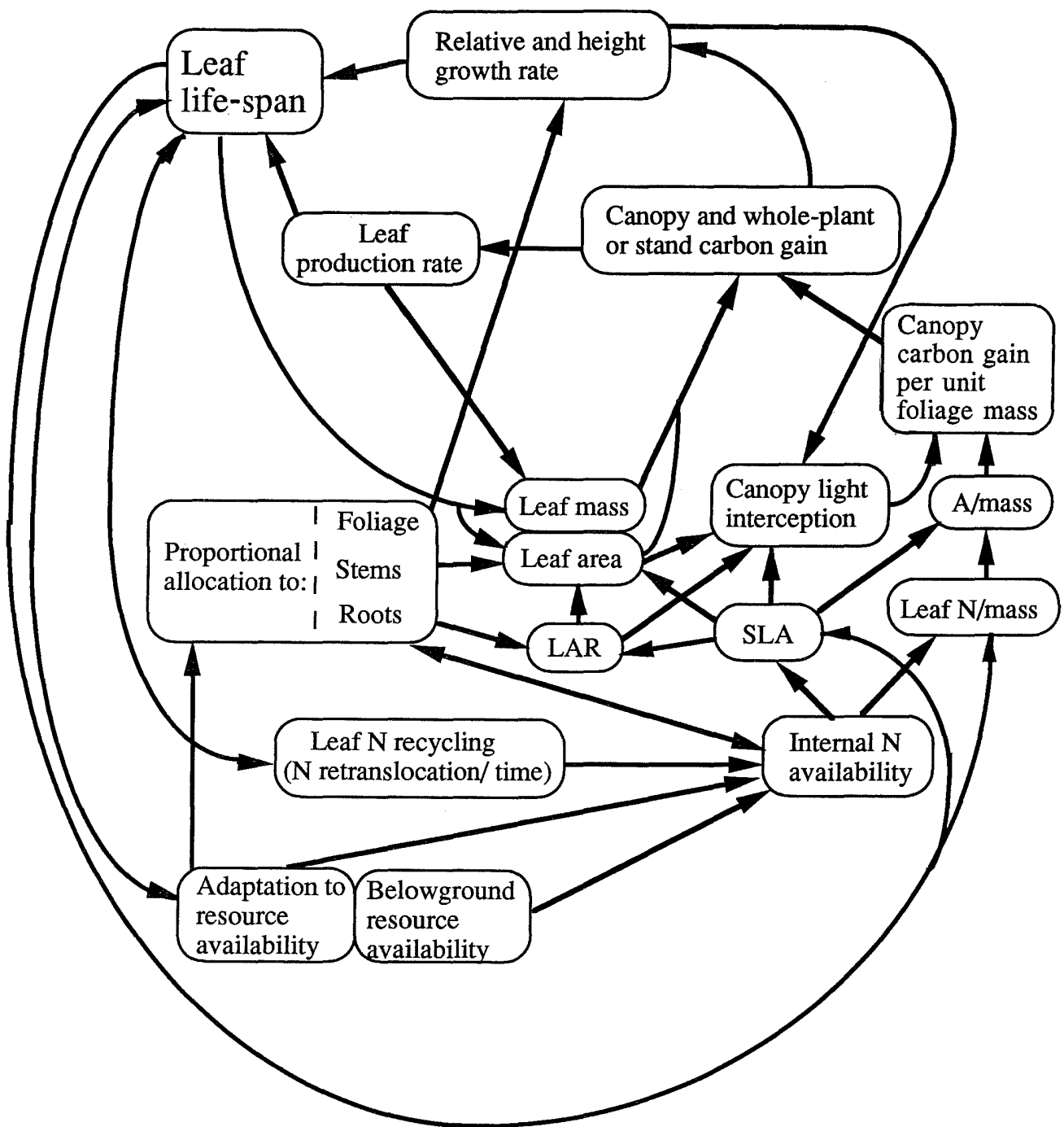

FIG. 9. Conceptual model of the interrelationships between allocation, metabolism, and patterns of carbon assimilation and distribution as affected by and affecting leaf life-span. For simplicity, and to be consistent with topics covered in this paper, the model focuses on $\mathrm{N}$ and does not consider the influence of other nutrients or water. However, the model is applicable to other resources such as these and their interactions would follow generally the pathways shown, as well as requiring additional ones. Influences of both adaptation and acclimation are addressed in the model. The model is applicable to young, individual, open-grown plants, and to forest stands. For instance, in young plants of species with short leaf life-span, high SLA and $\mathrm{N}_{\text {mass }}$ lead to high $A_{\text {mass }}$ and LAR, resulting in high plant carbon gain and growth that "feed back" to result in higher leaf area and mass, further accelerating carbon gain, growth rate, and leaf turnover rate. Young plants with long leaf life-span show opposite traits (e.g., low SLA, $A_{\text {mass }}$ ) that interact to result in low carbon gain and growth. However, as young plants grow into large trees and form closed-canopy forest stands, extended leaf life-span leads to the accumulation of high leaf mass and leaf area, that act to partially compensate for the traits that otherwise lead to low productivity.

to demonstrate. To do so one must show that specific plant traits can be related to survival in an ecologically realistic context (it could take years in some instances for ecologically important rates of mortality to occur), and demonstrate the trade-off between productivity and survival in the expression of a given trait.

Slow-growing species with long leaf life-spans may be adapted to low-resource habitats with different combinations of survival-enhancing plant traits (Korner
1991). For example, the traits necessary to cope with a boreal environment differ from those for a warm desert. Despite such differences across habitats, however, the physiological constraints imposed by those different traits may be similar, resulting in a tendency toward common values and relationships among growth, leaf life-span, and $\mathrm{CO}_{2}$ exchange rates. We should view these patterns, however, keeping in mind matters of scale. Strong relationships to leaf life-span 
of other leaf and plant traits indicate a powerful trend across broad gradients of habitats and species; within that trend there can be substantial and ecologically important variation.

Stand level. - In forest stands the relationships discussed above (for individual plants) are altered, probably due to the increasing complexity of canopies. In closed-canopy stands, species with shorter leaf lifespanshave greater rates of photosynthesis, leaf $\mathrm{N}_{\text {mass }}$, and SLA, which are probably responsible for their greater canopy production efficiency (ANPP/foliage mass) (Table 4, Fig. 7), but these are coupled with a low total (or proportional) foliage biomass, with the result (Fig. 9) that ANPP is not different than in species with longer leaf life-spans. The continuous presence of a photosynthetic surface and/or maintenance of a larger standing foliage biomass by trees with long leaf lifespans appears to compensate (in terms of ANPP) for lower rates of production efficiency by several means, including persistence of a canopy during periods when deciduous species are leafless, greater overall light interception, lower annual production of new foliage biomass per tree, and/or lower annual nutrient requirements (Waring and Franklin 1979, Cannell 1985, Gower et al. 1989). Differences in foliage morphology and display between deciduous broad-leaved and needleleaved evergreen species may also help the latter compensate for their low production efficiency by increasing light interception and by other means (Sprugel 1989, Gower and Richards 1990). Differences in needle morphology or clumping, or other whole-plant traits, between broad-leaved and needle-leaved species may also help to explain why ANPP was not related to leaf lifespan among all or only broad-leaved species, but was negatively related to leaf life-span among evergreen needle-leaved species alone.

In addition, fine root production and turnover rates, which can account for a large proportion of carbon and nutrient allocation in forest stands (Vogt et al. 1986), may vary among species with differing leaf life-span, and thus should be considered to the extent possible in any broad analysis of ecosystem processes vis-à-vis leaf life-span. However, given the lack of reliable information on belowground production and turnover rates, such analyses across species with differing leaf life-span may be premature at present (Gower and Richards 1990).

Nutrient use efficiency. - In this paper, we found a weak, negative relationship between leaf life-span and $A_{\text {leaf N }}$ (an index of instantaneous potential photosynthetic N use efficiency, PPNUE; e.g., Field and Mooney 1986). In contrast, we found a weak, but positive relationship between leaf life-span and litterfall-based NUE, often used as an index of long-term NUE (Vitousek 1982). Litterfall NUE and PPNUE were also weakly inversely related $\left(r^{2}=0.26\right)$. Why are trends for litterfall NUE vis-à-vis leaf life-span opposite to those for PPNUE? Perhaps the high PPNUE of short- lived leaves is offset by the brief life-span in terms of influence on longer term (time-integrated) nutrient use efficiency. To evaluate this possibility, it might be instructive to consider the index "life-span PPNUE" (PPNUE-leaf life-span, a crude relative index of maximum time-integrated potential carbon gain per unit leaf $\mathrm{N}$ ). This index is positively related to leaf life-span $\left(r^{2}=0.65\right.$ and 0.93 for LEAVES and SCRN data, respectively, Table 1) (i.e., extended leaf life-span overcompensates for a low PPNUE) and also to litterfall NUE $\left(P<.01, r^{2}=0.36\right)$.

However, the index "life-span PPNUE" ignores retranslocation of $\mathrm{N}$ and changes in photosynthetic capacity and light microenvironment with leaf aging. Although such limitations might negate any inferences reached using this index, the following considerations suggest that they do not. First, proportional retranslocation does not differ with respect to leaf life-span (Small 1972, Chapin and Kedrowski 1983; this study: Fig. 8B), suggesting that a long-term measure of carbon gained per unit leaf $\mathrm{N}$ should show a similar relationship to leaf life-span whether or not retranslocation is considered in such a calculation. Second, among species with differing leaf life-span, proportional declines in photosynthetic capacity with increasing leaf age appear roughly proportional to the total leaf life-span. If any trend is apparent it suggests maintenance of proportionally high carbon gain proportionally longer for species with long-lived foliage (Koike 1988; P. B. Reich et al., unpublished data). Therefore, even though "lifespan-PPNUE" is based on $A_{\max }$ at a single leaf age, this should not markedly affect the overall relationship of long-term carbon gain per unit leaf $\mathrm{N}$ to leaf life-span, or nudge it further in "favor" of extended longevity. Third, low light availability (due to self-shading) to older leaves of "high-LAI/long leaf life-span" species should reduce carbon gain per unit foliage, but most species with high LAI are relatively shade tolerant and saturate photosynthetically at relatively low light levels. In contrast, the theoretically lesser degree of shading on an older short-lived leaf might reduce its photosynthetic rates just as much, given its likely high $A_{\text {mass }}$ and light saturation point. Definitive analyses of integrated long-term NUE based on physiological measurements remain to be made.

Although two distinct indices (litterfall NUE and life-span PPNUE) suggest that long-term NUE increases with leaf life-span, it is not possible from these data to determine whether greater NUE is an intrinsic characteristic of greater leaf longevity or a phenotypic response to the generally lower nutrient availability of sites where such species are commonly found. Litterfall NUE did not differ significantly among five species with large variation in leaf life-span when they were compared on adjacent sites that did not differ in $\mathrm{N}$ availability (Son 1991) and in fact, ANPP/annual N uptake was negatively correlated with leaf life-span (Son and Gower 1991). 
Other ecological considerations. - Species with the mutually supporting traits, high $\mathrm{N}_{\text {mass }}$, SLA, and $A_{\text {mass }}$ and short leaf life-span, tend to inhabit either generally resource-rich environments or spatial and/or temporal microhabitats that are resource rich in otherwise more limited habitats (e.g., "precipitation" ephemerals in warm deserts or spring ephemerals in the understory of temperate deciduous forests). In contrast, species with the longest leaf life-span, low SLA, $\mathrm{N}_{\text {mass }}$, and $A_{\text {area }}$ are either conifers growing in low-temperature limited, dry, and/or nutrient-poor environments, or evergreen broadleaf species inhabiting nutrient-poor environments (e.g., Small 1972, Chapin 1980, Reich et al. 1991a). For example, species with long or short leaf life-spans appear to be restricted to nutrient-poor or nutrient-rich soils, respectively, in eastern North American forests (e.g., Monk 1966, Small 1972, Chapin 1980, Hicks and Chabot 1985), in ecosystems in the northern Amazon basin (Cuevas and Medina 1986, Uhl 1987, P. B. Reich et al., 1991 $a$ and unpublished data), and in the Great Basin of the western U.S. (Schlesinger et al. 1989).

Species with short and long leaf life-span tend to be early and late secondary successional, respectively, although there is substantial variation within these trends (Koike 1988; LEAVES, GROWTH, HEIGHT, STAND, and NITROGEN data sets, this paper). This pattern is consistent with variation in resource availability (especially nutrients), since resources are usually high early in secondary succession and decrease with time on most sites if not chronically or catastrophically disturbed (Vitousek et al. 1989). The more than ninefold variation in leaf $\mathrm{N}_{\text {mass }}$ and its strong relationship to leaf life-span, $A_{\text {mass }}$, and RGR (Fig. 1, Tables 1-3) also supports the idea that variation in leaf life-span may be related to nutrient availability and successional gradients. Despite the highly significant relations reported in this paper, there is substantial unexplained variation in the relationships between leaf life-span and other traits such as $A_{\text {mass }}, \mathrm{N}_{\text {mass }}$, or SLA in both a single ecosystem (Amazonia) and in data from many biomes (LEAVES). Certainly, some proportion of this must be attributed to experimental error, but we also ask whether we can explain any of this variation biologically. For instance, despite a strong correlation $\left(r^{2}=0.70\right)$ in the LEAVES survey, different species with similar leaf lifespans can have large differences in $A_{\text {mass }}$ (as much as fourfold) that are only small in comparison to the 75 fold range of rates across all life-spans. Are there any consistent sources of such variation for a given leaf life-span?

Deciduous plants that inhabit biomes with marked unfavorable seasons (cold and/or dry) appear to be one such candidate. For instance, in northern temperate forests of eastern North America, one observes an almost complete discontinuity in the distribution of leaf life-spans among species (many with life-spans $<7$ mo or $>18 \mathrm{mo}$, with few in between). Numerous species retain leaves for $\approx 6 \mathrm{mo}$. Among these species there is relatively large variation in leaf traits, ecological niche, etc. Perhaps in strongly seasonal climates that favor a given leaf life-span, the numerous species that share this leaf life-span might be expected to have evolved greater variation in other leaf or whole-plant traits than would otherwise occur for species with similarity in leaf life-span.

It is also possible that ecosystems with different types of resource limitations or stresses (e.g., deserts, tundra, rain forests) might display significant differences with respect to the relationships between leaf life-span and related traits, within the general trends shown in Figs. 1-8. For instance, species from a given ecosystem (or biome) might have substantially greater (or lesser) values of $A_{\text {mass }}, \mathrm{SLA}$, or $\mathrm{N}_{\text {mass }}$ for any given leaf life-span than species from another type of system. The data in the present paper are insufficient to address this question, so we are currently collecting data from six ecologically and geographically distinct ecosystems specifically to test such a hypothesis (P. B. Reich et al., unpublished data).

Evergreen vs. deciduous behavior. - The contrast of evergreen and deciduous species, and the implications that emerge from such comparisons, is a paradigm of modern ecological thought (e.g., Monk 1966, Schulze et al. 1977, Chapin 1980, Chabot and Hicks 1982, Sprugel 1989, and others). However, based on the data presented in this paper, deciduous species with leaves that persist for 9-10 mo are likely to share more closely traits with evergreen species that retain foliage for 2$3 \mathrm{yr}$ than with deciduous species that keep leaves for 2-3 mo. In a similar fashion, evergreen species with intermediate leaf lifetimes (e.g., Pinus strobus) are likely to be just as different from evergreens with long-leaf lifetimes (such as Picea glauca) as deciduous species with short-lived leaves (e.g., young Populus deltoides) are from other deciduous species with slightly longer leaf lifetimes (e.g., young Quercus rubra). Thus, our tendency to "lump" all temperate evergreens with leaf lifetimes $>1 \mathrm{yr}$ and compare them with deciduous plants with lifetimes of $<1$ yr may be misleading in certain instances. Clearly, the deciduous-evergreen contrast, although useful in several ways not mentioned here, should be viewed from the broader perspective of a gradient of variation in leaf life-span.

Many of our assumptions about evergreen and deciduous habit (e.g., associating deciduousness with high SLA, $A_{\max }$, and $\mathrm{N}_{\text {mass }}$ ) apply only to the extent that evergreenness is associated with long leaf life-spans. For example, many tropical rain forest species are evergreen, yet have leaf lifetimes of $<1 \mathrm{yr}$ (e.g., Reich et al. 1991a) and have leaf traits (high SLA, N, $A_{\max }$ ) that are similar to those of deciduous plants (from other biomes) with similar leaf lifetimes. Therefore, we should recognize that the differences in leaf traits we associate with evergreen vs. deciduous contrasts are a result primarily of differences in leaf life-span, and not with 
anything intrinsic in the evergreen vs. nonevergreen habit per se. Clearly the evergreen-deciduous paradigm has evolved through work in boreal, temperate, mediterranean-type, and desert biomes, and in such environments the contrasts between deciduous and evergreen plants are roughly parallel to those of differing leaf life-spans, since evergreen plants generally have only long leaf lifetimes in those environments.

While there are other leaf traits in evergreen plants in seasonally harsh environments (e.g., cold hardiness, desiccation tolerance) that are not displayed to the same degree by deciduous species in the same environments, such differences can still be explained within the same cost-benefit framework used for plants from nonseasonal environments. Since such survival mechanisms are not directly productive and are likely to be costly, they are conceptually and perhaps chemically and physically similar to other traits associated with longer leaf lifetimes.

\section{CONCLUSIONS}

The data and analyses in this study, considered along with prior research as cited above, suggest the following general conclusions.

1) There is a strong interdependency among leaflifespan, net photosynthetic rate, leaf $\mathrm{N}$ concentration, SLA, and habitat resource availability that may result from the necessity for allocational trade-offs that either enhance productivity or persistence (Chapin 1980, Coley et al. 1985, Reich et al. 1991a). Although this paper has focused on leaf life-span, the data suggest that this trait is so closely interrelated with several others that we should consider this cohort of leaf traits as causally interrelated, rather than being unidirectionally dependent on each other. These co-dependent leaf traits interact to both influence and reflect growth rates of individual juvenile plants and the production efficiency of closed-canopy forest stands. Apparently a plant either can produce leaves that possess a high photosynthetic assimilation rate but persist briefly, or it can provide resistant leaf physical structure with lower photosynthetic capacity, so that leaves can assimilate carbon over a longer period of time, but at a lower rate. This trade-off has important ecological ramifications, because differences between species in leaflifespan and associated traits reflect their differences in growth rate (both RGR and height growth) and in microhabitat.

2) Broad variation in $\mathrm{N}_{\text {mass }}, A_{\text {mass }}$ (and less so $A_{\text {area }}$ and $A_{\text {leaf N }}$ ), SLA, RGR, and height growth rate, and stand-level canopy production efficiency occur in fixed quantitative relationships to variation in leaf life-span, and to each other, among species from diverse ecosystems and biomes, regardless of differences in climate, resource availability, leaf form, or seasonal stresses. Therefore, for any given leaf lifetime, species should have roughly similar values for a number of leaf, whole-plant, and stand-level traits.
3) Despite the numerous similarities noted above, young isolated individuals and stands of mature trees have a fundamental difference related to leaf life-span that impacts significantly on productivity. In mature stands, species with longer leaf life-spans accumulate great absolute and proportional foliage mass and area, that compensates for low leaf-level productivity and enables these species to have ANPP similar to species with short leaf life-spans. As young individuals, species with longer leaf life-spans have similar or lower proportional allocation to foliage mass and area (than those with shorter leaf life-spans), that combine with low leaf-level productivity to result in low RGR or height growth rates.

4) Because species with similar leaf life-spans from dissimilar ecosystems or biomes have a number of other traits in common, we may be able to predict their general response to other biotic or abiotic stresses, such as air pollution (Reich 1987), herbivory (Coley 1988), or climate change, based on their leaf lifetimes.

\section{ACKNOWLEDGMENTS}

We thank two anonymous referees and Chris Field for insightful critical reviews of earlier versions of this manuscript; Tom Gower for many stimulating discussions relative to this topic; and the numerous cited authors whose data and ideas contributed directly and indirectly to this work. This research was partially supported by National Science Foundation Grants BSR 8819718 and BSR 8857129.

\section{Literature Cited}

Aber, J. D., J. M. Melillo, K. J. Nadelhoffer, C. A. McClaugherty, and J. Pastor. 1985. Fine root turnover in forest ecosystems in relation to quantity and form of nitrogen availability: a comparison of two methods. Oecologia (Berlin) 66:317-321.

Abul-Fatih, H. A., and F. A. Bazzaz. 1980. The biology of Ambrosia trifida L. IV. Demography of plants and leaves. New Phytologist 84:107-111.

Aerts, R. 1990. Nutrient use efficiency in evergreen and deciduous species from heathlands. Oecologia (Berlin) 84: 391-397.

Agren, G. I., and T. Ingestad. 1987. Root: shoot ratio as a balance between nitrogen productivity and photosynthesis. Plant, Cell and Environment 10:579-586.

Amundson, R. G., R. M. Raba, A. W. Schoettle, and P. B. Reich. 1986. Response of soybean to low concentrations of ozone. II. Effects on growth, biomass allocation and flowering. Journal of Environmental Quality 15:161-167.

Axelrod, D. I. 1966. Origin of deciduous and evergreen habits in temperate forests. Evolution 20:1-15.

Baskerville, G. L. 1965. Dry matter production in immature balsam fir stands. Forest Science Monograph 9.

Bazzaz, F. A. 1979. The physiological ecology of plant succession. Annual Review of Ecology and Systematics 10: 351-371.

Bazzaz, F. A., and J. L. Harper. 1977. Demographic analysis of the growth of Linum usitatissimum. New Phytologist 78: 193-208.

Benecke, U., E.-D. Schulze, R. Matyssek, and W. M. Havranek. 1981. Environmental control of $\mathrm{CO}_{2}$ assimilation and leaf conductance in Larix decidua Mill. I. A comparison of contrasting natural environments. Oecologia (Berlin) 50: 54-61.

Bockheim, J. G., S. W. Lee, and J. E. Leide. 1983. Distribution and cycling of elements in a Pinus resinosa plan- 
tation ecosystem, Wisconsin. Canadian Journal of Forest Research 13:609-619.

Bray, J. R., and L. A. Dudkiewicz. 1963. The composition, biomass and productivity of two Populus forests. Bulletin of the Torrey Botanical Club 90:298-308.

Bray, J. R., and E. Gorham. 1964. Litter production in forests of the world. Advances in Ecological Research 2: 101-158.

Briggs, G. M., T. W. Jurik, and D. M. Gates. 1986. A comparison of aboveground growth and carbon dioxide assimilation by aspen on sites of high and low quality. Tree Physiology 2:29-34.

Bunce, J. A. 1989. Growth rate, photosynthesis and respiration in relation to leaf area index. Annals of Botany 63: 459-463.

-1990. Short- and long-term inhibition of respiratory carbon dioxide efflux by elevated carbon dioxide. Annals of Botany 65:637-642.

Burgess, D. 1990. White and black spruce seedling development using the concept of relative addition rate. Scandinavian Journal of Forest Research 5:471-480.

Cannell, M. G. R. 1982. World forest biomass and primary production data. Academic Press, London, England.

. 1985. Dry matter partitioning in tree crops. Pages 160-193 in M. Cannell and J. Jackson, editors. Attributes of trees as crop plants. Institute of Terrestrial Ecology, Monks Wood, Abbots Ripton, Hunts, England.

Carlyle, J. C., and D. C. Malcolm. 1986. Larch litter and nutrient availability in mixed larch-spruce stands. I. Nutrient withdrawal, redistribution and leaching losses from larch foliage and senescence. Canadian Journal of Forest Research 16:321-326.

Carmean, W. H. 1975. Forest site quality evaluation in the United States. Advances in Agronomy 27:207-269.

Carter, G. A., and W. K. Smith. 1988. Microhabitat comparisons of transpiration and photosynthesis in three subalpine conifers. Canadian Journal of Botany 66:963-969.

Chabot, B. F., and D. J. Hicks. 1982. The ecology of leaf life spans. Annual Review Ecology and Systematics 13:229259.

Chapin, F. S., III. 1980. The mineral nutrition of wild plants. Annual Review Ecology and Systematics 11:233-260.

Chapin, F. S., III, and R. A. Kedrowski. 1983. Seasonal changes in nitrogen and phosphorus fractions and autumnal retranslocation in evergreen and deciduous taiga trees. Ecology 64:376-391.

Chazdon, R. L., and C. B. Field. 1987. Determinants of photosynthetic capacity in six rainforest Piper species. Oecologia (Berlin) 73:222-230.

Cole, D. W., and M. R. Rapp. 1981. Elemental cycling in forest ecosystems. Pages 341-409 in D. Reichle, editor. Dynamic properties of forest ecosystems. International Biological Program Synthesis Volume 23. Cambridge University, Cambridge, England.

Coley, P. D. 1988. Effects of plant growth rate and leaf lifetime on the amount and type of anti-herbivore defense. Oecologia (Berlin) 74:531-536.

Coley, P. D., J. P. Bryant, and F. S. Chapin, III. 1985. Resource availability and plant anti-herbivore defense. Science 230:895-899.

Comeau, P. G., and J. P. Kimmins. 1986. The relationship between net primary production and foliage nitrogen content, and its application to the modelling of forest ecosystems: a study of lodgepole pine (Pinus contorta). Pages 202223 in T. Fujimori and D. Whitehead, editors. Crown and canopy structure in relation to productivity. Forestry and Forest Products Research Institute, Ibaraki, Japan.

Comstock, J., and J. Ehleringer. 1984. Photosynthesic responses to slowly decreasing leaf water potentials in Encelia frutescens. Oecologia (Berlin) 61:241-248.
Comstock, J., and J. Ehleringer. 1986. Canopy dynamics and carbon gain in response to soil water availability in Encelia frutescens gray, a drought-deciduous shrub. Oecologia (Berlin) 68:271-278.

Cuevas, E., and E. Medina. 1986. Nutrient dynamics within amazonian forest ecosystems. I. Nutrient flux in fine litterfall and efficiency of nutrient utilization. Oecologia (Berlin) 68:466-472.

Damman, A. W. H. 1964. Some forest types of central Newfoundland and their relation to environmental factors. Forest Science Monograph 8.

- 1971. Effect of vegetation changes on the fertility of a Newfoundland forest site. Ecological Monographs 41: 253-270.

Day, F. P., and C. D. Monk. 1977a. Net primary production and phenology on a southern Appalachian watershed. American Journal of Botany 64:1117-1125.

Day, F. P., and C. D. Monk. 1977b. Seasonal nutrient dynamics in the vegetation on a southern Appalachian watershed. American Journal of Botany 64:1126-1139.

De Angelis, D. L., R. H. Gardner, and H. H. Shugart. 1981. Productivity of forest ecosystems studied during the IBP: the Woodlands data set. Pages 567-672 in D. E. Reichle, editor. Dynamic properties of forest ecosystems. International Biological Programme 23. Cambridge University Press, London, England.

del Arco, J. M., A. Escudero, and M. Vega Garrido. 1991. Effects of site characteristics on nitrogen retranslocation from senescing leaves. Ecology 72:701-708.

DeLucia, E. H., and W. K. Smith. 1987. Air and soil temperature limitations on photosynthesis in Engelmann spruce during summer. Canadian Journal of Forest Research 17: 527-533.

Dornhoff, G. M., and R. M. Shibles. 1970. Variety differences in net photosynthesis of soybean leaves. Crop Science 10:42-45.

Doucet, R., J. V. Berglund, and C. E. Farnsworth. 1976. Dry matter production in 40-year-old Pinus banksiana stands in Quebec. Canadian Journal of Forest Research 6:357367.

Ewers, F. W., and R. Schmid. 1981. Longevity of needle fascicles of Pinus longaeva (bristlecone pine) and other North American pines. Oecologia (Berlin) 51:107-115.

Field, C. 1988. On the role of photosynthetic responses in constraining the habitat distribution of rainforest plants. Australian Journal of Plant Physiology 15:343-358.

Field, C., J. Merino, and H. A. Mooney. 1983. Compromises between water-use efficiency and nitrogen-use efficiency in five species of California evergreens. Oecologia (Berlin) 60:84-89.

Field, C., and H. A. Mooney. 1986. The photosynthesisnitrogen relationship in wild plants. Pages $25-55$ in T. Givnish, editor. On the economy of plant form and function. Cambridge University Press, London, England.

Fischer, R. A., F. Bidinger, J. R. Syme, and P. C. Wall. 1981. Leaf photosynthesis, leaf permeability, crop growth, and yield of short spring wheat genotypes under irrigation. Crop Science 21:367-373.

Forseth, I. N., and J. R. Ehleringer. 1982. Ecophysiology of two solar tracking desert winter annuals. II. Leaf movements, water relations and microclimate. Oecologia (Berlin) 54:41-49.

Forseth, I. N., and J. R. Ehleringer. 1983. Ecophysiology of two solar tracking desert winter annuals. IV. Effects of leaf orientation on calculated daily carbon gain and water use efficiency. Oecologia (Berlin) 58:10-18.

Fownes, J. H. 1985. Water use and primary production of Wisconsin hardwood forests. Dissertation. University of Wisconsin, Madison, Wisconsin, USA.

Fujimori, T., S. Kawanabe, H. Saito, C. C. Grier, and T. 
Shidei. 1976. Biomass and primary production in forests of three major vegetation zones of the northwestern United States. Journal of Japanese Forest Society 58:360-373.

Gholz, H. L. 1982. Environmental limits on aboveground net primary production, leaf area, and biomass in vegetation zones of the Pacific Northwest. Ecology 63:469-481.

Gill, D. S., and B. E. Mahall. 1986. Quantitative phenology and water relations of an evergreen and a deciduous chaparral shrub. Ecological Monographs 56:127-143.

Golley, G. B., J. T. McGinnis, and R. G. Clements. 1971. La biomasa y la estructura mineral de algunos bosques de Darién, Panama. Turrialba 21:189-196.

Gordon, A. G. 1981. Pages 576-579 in D. E. Reichle, editor. Dynamic properties of forest ecosystems. Cambridge University Press, Cambridge, England.

Gosz, J. R. 1980. Biomass distribution and production budget for a non-aggrading forest ecosystem. Ecology 61:507514.

- 1981. Nitrogen cycling in coniferous ecosystems. In F. E. Clark and T. Rosswall, editors. Terrestrial nitrogren cycles. Ecological Bulletins-NFR 33:405-426.

Gower, S. T., C. C. Grier, and K. A. Vogt. 1989. Aboveground production and $\mathrm{N}$ and $\mathrm{P}$ use by Larix occidentalis and Pinus contorta in the Washington Cascades, USA. Tree Physiology 5:1-11.

Gower, S. T., and J. H. Richards. 1990. Larches: deciduous conifers in an evergreen world. BioScience 40:818-826.

Gower, S. T., P. B. Reich, and Y. Son. 1992. Leaf longevity and its control on canopy structure and carbon assimilation by five tree species. Oecologia (Berlin), in press.

Gray, J. T. 1982. Community structure and productivity in Ceanothus chaparral and coastal sage shrub of southern California. Ecological Monographs 52:415-435.

Gray, J. T., and W. H. Schlesinger. 1983. Nutrient use by evergreen and deciduous shrubs in southern California. II. Experimental investigations of the relationships between growth, nitrogen uptake and nitrogen availability. Journal of Ecology 71:43-56.

Grier, C. C., K. A. Vogt, M. R. Keyes, and R. L. Edmonds. 1981. Biomass distribution and above- and below-ground production in young and mature Abies amabilis zone ecosystems of the Washington Cascades. Canadian Journal of Forest Research 11:155-167.

Grime, J. P., and R. Hunt. 1975. Relative growth rate: its range and adaptive significance in a local flora. Journal of Ecology 63:393-422.

Harley, P. C., J. D. Tenhunen, W. Beyschlag, and O. L. Lange. 1987. Seasonal changes in net photosynthesis rates and photosynthetic capacity in leaves of Citrus salvifolius, a European Mediterranean semi-deciduous shrub. Oecologia (Berlin) 74:380-388.

Harrington, R. A., B. J. Brown, and P. B. Reich. 1989. Ecophysiology of exotic and native shrubs in Southern Wisconsin. I. Relationship of leaf characteristics, resource availability, and phenology to seasonal patterns of carbon gain. Oecologia (Berlin) 80:356-367.

Heilman, P. E., and R. F. Stettler. 1985. Genetic variation and productivity of Populus trichocarpa T. \& G. and its hybrids. II. Biomass production in a 4 -year plantation. Canadian Journal of Forest Research 15:384-388.

Hicks, D. J., and B. F. Chabot. 1985. Deciduous forest. Pages 257-277 in B. F. Chabot and H. A. Mooney, editors. Physiological ecology of North American plant communities. Chapman and Hall, New York, New York, USA.

Hiroi, T., and M. Monsi. 1966. Dry-matter economy of Helianthus annuus communities grown at varying densities and light intensities. Journal of Faculty of Sciences University of Tokyo III, 9:241-285.

Hirose, T., and M. J. A. Werger. 1987. Maximizing daily canopy photosynthesis with respect to the leaf allocation pattern in the canopy. Oecologia (Berlin) 72:520-526.
Hom, J. L., and W. C. Oechel. 1983. The photosynthetic capacity, nutrient content, and nutrient use efficiency of different needle age-classes of black spruce (Picea mariana) found in interior Alaska. Canadian Journal of Forest Research 13:834-839.

Hunt, R., and P. S. Lloyd. 1987. Growth and partitioning. New Phytology 106:235-249.

Hytteborn, H. 1975. Deciduous woodland at Andersby, eastern Sweden: above-ground tree and shrub production. Acta Phytogeographica Suecica 61.

Ingestad, T. 1976. Nitrogen and cation nutrition of three ecologically different plant species. Physiologia Plantarum 38:29-34.

- 1979a. Mineral nutrient requirements of Pinus sylvestris and Picea abies seedlings. Physiologia Plantarum 45: 373-380.

- $1979 b$. Nitrogen stress in birch seedlings. II. N, K, $\mathrm{P}, \mathrm{Ca}$ and $\mathrm{Mg}$ nutrition. Physiologia Plantarum 45:149157.

157. 1981. Nutrition and growth of birch and grey alder seedlings in low conductivity solutions and at varied relative rates of nutrient additions. Physiologia Plantarum 52: 454-466.

Ingestad, T., and M. Kahr. 1985. Nutrition and growth of coniferous seedlings at varied relative nitrogen addition rate. Physiologia Plantarum 65:109-116.

Ingestad, T., and A. B. Lund. 1979. Nitrogen stress in birch seedlings. I. Growth technique and growth. Physiologia Plantarum 45:137-148.

Jarvis, P. G., and M. S. Jarvis. 1964. Growth rates of woody plants. Physiologia Plantarum 17:654-666.

Jia, H., and T. Ingestad. 1984. Nutrient requirements and stress response of Populus simonii and Paulownia tomentosa. Physiologia Plantarum 62:117-124.

Johnson, D. A., and L. L. Tieszen. 1976. Aboveground biomass allocation, leaf growth, and photosynthesis patterns in tundra plant forms in arctic Alaska. Oecologia (Berlin) 24:159-173.

Johnson, F. L., and P. G. Risser. 1974. Biomass, annual net primary production and dynamics of six mineral elements in a post oak-blackjack oak forest. Ecology 55:1246-1258.

Jonasson, S. 1989. Implications of leaf longevity, leaf nutrient re-absorption and translocation for the resource economy of five evergreen plant species. Oikos 56:121-131.

Jordan, C. F., and C. Uhl. 1978. Biomass of a 'terra firma' forest of the Amazon Basin. Oecologia (Berlin) 13:384-400.

Jow, W. M., S. H. Bullock, and J. Kummerow. 1980. Leaf turnover rates of Adenostoma fasciculatum (Rosaceae). American Journal of Botany 67:256-261.

Jurik, T. W. 1980. Physiology, growth, and life-history characteristics of Fragaria virginiana Duchesne and $F$. vesca $\mathrm{L}$. (Rosaceae). Dissertation. Cornell University, Ithaca, New York, USA.

- 1986a. Seasonal patterns of leaf photosynthetic capacity in successional northern hardwood tree species. American Journal of Botany 73:131-138.

1986b. Temporal and spatial patterns of specific leaf weight in successional northern hardwood tree species. American Journal of Botany 73:1083-1092.

Jurik, T. W., J. A. Weber, and D. M. Gates. 1988. Effects of temperature and light on photosynthesis of dominant species of a northern hardwood forest. Botanical Gazette 149:203-208.

Kachi, N., and L. H. Rorison. 1989. Optimal partitioning between root and shoot in plants with contrasted growth rates in response to nitrogen availability and temperature. Functional Ecology 3:549-559.

Kanazawa, Y., and A. Sato. 1986. Stem growth of Leucaena leucocepahla (Lam.) De Wit in relation to leaf life-span. Pages 190-221 in T. Fujimori and D. Whitehead, editors. 
Crown and canopy structure in relation to productivity. Forestry and Forest Products Research Institute, Ibaraki, Japan.

Karlsson, P. S. 1989. In situ photosynthetic performance of four coexisting dwarf shrubs in relation to light in a subarctic woodland. Functional Ecology 3:481-487.

Kato, R., Y. Tadaki, and H. Ogawa. 1978. Plant biomass and growth increment studies in Pasoh forest. Malay Nature Journal 30:211-224.

Kawahara, T., Y. Takaki, I. Takeuchi, A. Sato, K. Higuchi, and K. Kamo. 1979. Productivity and cycling of organic matter in natural Fagus crenata and two planted Chamaecyparis obtusa forests. Japanese Journal of Ecology 29:387395.

Keyes, M. R., and C. C. Grier. 1981. Above- and belowground net primary production in 40-year-old Douglas-fir stands on low and high productivity sites. Canadian Journal of Forest Research 11:599-605.

Kikuzawa, K. 1983. Leaf survival of woody plants in deciduous broad-leaved forests. 1. Tall trees. Canadian Journal of Botany 61:2133-2139.

- 1984. Leaf survival of woody plants in deciduous broad-leaved forests. 2. Small trees and shrubs. Canadian Journal of Botany 62:2551-2556.

Kira, T. 1978. Community architecture and organic matter dynamics in tropical lowland rainforests of southwestern Asia with special reference to Pasoh Forest, west Malaysia. Pages 561-590 in P. B. Tomlinson and M. H. Zimmerman, editors. Tropical trees as living systems. Cambridge University Press, Cambridge, England.

Klinge, H., and W. A. Rodrigues. 1968a. Litter production in an area of Amazonian terra firme forest. Part 1. Litterfall, organic carbon and total nitrogen contents of litter. Amazoniana 1:287-302.

Klinge, H., and W. A. Rodriques. 1968b. Litter production in an area of Amazonian terra firma forest. Part II. Mineral nutrient content of the litter. Amazoniana 1:303-310.

Klinka, K., and R. E. Carter. 1990. Relationships between site index and synoptic environmental factors in immature coastal douglas-fir stands. Forest Science 36:815-830.

Koerper, G. J., and C. J. Richardson. 1980. Biomass and net annual primary production regressions for Populus grandidentata on three sites in northern lower Michigan. Canadian Journal of Forest Research 10:92-101.

Koike, T. 1988. Leaf structure and photosynthetic performance as related to the forest succession of deciduous broadleaved trees. Plant Species Biology 3:77-87.

Koike, T., Y. Sakagami, and Y. Fugimura. 1986. Characteristics of the leaf dynamics and the photosynthesis of the seedlings and saplings of Betula maximowicziana and Fraxinus mandshurica var. japonica in Hokkaido, Japan. Pages 396-408 in T. Fujimori and D. Whitehead, editors. Crown and canopy structure in relation to productivity. Forestry and Forest Products Research Institute, Ibaraki, Japan.

Korner, C. 1991. Some often overlooked plant characteristics as determinants of plant growth: a reconsideration. Functional Ecology 5:162-173.

Kozlowski, T. T., and R. C. Ward. 1957a. Seasonal height growth of conifers. Forest Science 3:61-66.

Kozlowski, T. T., and R. C. Ward. 1957b. Seasonal height growth of deciduous trees. Forest Science 3:168-174.

Krinard, R. M. 1985. Ten years' growth of pruned and unpruned cottonwood planted at 40 - by 40 -foot spacing. United States Department of Agriculture Forest Service Research Note SO-316.

Küppers, M. 1984a. Carbon relations and competition between woody species in a Central European hedgerow. I. Photosynthetic characteristics. Oecologia (Berlin) 64:332343.

- 1984b. Carbon relations and competition between woody species in a Central European hedgerow. II. Stomatal response, water use, and hydraulic conductivity in the root/ leaf pathway. Oecologia (Berlin) 64:344-354.

Küppers, M., G. Koch, and H. A. Mooney. 1988. Compensating effects to growth of changes in dry matter allocation in response to variation in photosynthetic characteristics induced by photoperiod, light and nitrogen. Australian Journal of Plant Physiology 15:287-298.

Lajtha, K., and W. G. Whitford. 1989. The effect of water and nitrogen amendments on photosynthesis, leaf demography, and resource-use efficiency in Larrea tridentata, a desert evergreen shrub. Oecologia (Berlin) 80:341-348.

Linder, S., and E. Troeng. 1980. Photosynthesis and transpiration of 20-year-old scots pine. Ecological BulletinsNFR 32:165-181.

Loach, K. 1970. Shade tolerance in tree seedlings. II. Growth analysis of plants raised under artificial shade. New Phytologist 69:273-286.

Loehle, C. 1988. Tree life history strategies: the role of defenses. Canadian Journal of Forestry Research 18:209-222.

Logan, K. T. 1965a. Growth of tree seedlings as affected by light intensity. I. White birch, yellow birch; sugar maple and silver maple. Department of Forestry of Canada Publication Number 1121.

- $1965 b$. Growth of tree seedlings as affected by light intensity. II. Red pine, white pine, jack pine and eastern larch. Department of Forestry of Canada Publication Number 1160.

-1966. Growth of tree seedlings as affected by light intensity. III. Basswood and white elm. Department of Forestry of Canada Publication Number 1176.

Lugg, D. G., and T. R. Sinclair. 1981. Seasonal changes in photosynthesis of field-grown soybean leaflets. 2. Relation to nitrogen content. Photosynthetica 15:138-144.

MacLean, D. A., and R. W. Wein. 1976. Biomass of jack pine and mixed hardwood stands in northeastern New Brunswick. Canadian Journal of Forest Research 6:441447.

MacLean, D. A., and R. W. Wein. 1978. Litter production and forest floor nutrient dynamics in pine and hardwood stands of New Brunswick, Canada. Holarctic Ecology 1:115.

Madgwick, H. A. I. 1968. Seasonal changes in biomass and annual production of an old field Pinus virginiana stand. Ecology 49:149-152.

Mahall, B. E., and F. H. Bormann. 1978. A quantitative description of the vegetative phenology of herbs in a northern hardwood forest. Botanical Gazette 139:467-481.

Mälkönen, E. 1975a. Annual primary production and nutrient cycle in some Scots pine stands. Communicationes Instituti Forestalis Fenniae 84:1-87.

- $1975 b$. Annual primary production and nutrient cycle in a birch stand. Communicationes Instituti Forestalis Fenniae 91:1-35.

Matyssek, R. 1986. Carbon, water and nitrogen relations in evergreen and deciduous conifers. Tree Physiology 2:177187.

McDonald, A. J., T. Lohammar, and A. Ericsson. 1986. Growth response to step-decrease in nutrient availability in small birch (Betula pendula Roth). Plant, Cell and Environment 9:427-432.

Merino, J., C. Field, and H. A. Mooney. 1982. Construction and maintenance costs of mediterranean-climate evergreen and deciduous leaves. I. Growth and $\mathrm{CO}_{2}$ exchange analysis. Oecologia (Berlin) 53:208-213.

Merino, J., C. Field, and H. A. Mooney. 1984. Construction and maintenance costs of mediterranean-climate evergreen and deciduous leaves. II. Biochemical pathway analysis. Acta Oecologia 5:211-223.

Miller, H. G., J. M. Cooper, and J. D. Miller. 1976. Effect on nitrogen supply on nutrients in litterfall and crown leach- 
ing in a stand of Corsican pine. Journal of Applied Ecology 13:233-248.

Miller, H. G., and J. D. Miller. 1976. Effect of nitrogen supply on net primary production in Corsican Pine. Journal of Applied Ecology 13:249-256.

Minckler, L. S., and J. D. Woerheide. 1968. Weekly height growth of cottonwood. Forest Science 14:212-222.

Miyaji, K. 1984. Longevity and productivity of leaves of a cultivated annual, Glycine max Merrill. II. Productivity of leaves in relation to their longevity, plant density and sowing time. New Phytologist 97:479-488.

Miyaji, K., and H. Tagawa. 1979. Longevity and productivity of leaves of a cultivated annual, Glycine max Merrill. I. Longevity of leaves in relation to density and sowing time. New Phytologist 82:233-244.

Monk, C. D. 1966. An ecological significance of evergreenness. Ecology 47:504-505.

Mooney, H. A., and S. L. Gulmon. 1982. Constraints on leaf structure and functions in reference to herbivory. BioScience 32:198-206.

Mooney, H. A., C. Field, S. L. Gulmon, and F. A. Bazzaz. 1981. Photosynthetic capacity in relation to leaf position in desert versus old-field annuals. Oecologia (Berlin) 50: 109-112.

Mooney, H. A., and P. W. Rundel. 1979. Nutrient relations of the evergreen shrub, Adenostoma fasciculatum, in the California chaparral. Botanical Gazette 140:109-113.

Miooney, H. A., M. West, and R. Brayton. 1966. Field measurements of the metabolic responses of bristlecone pine and big sagebrush in the White Mountains of California. Botanical Gazette 127:105-113.

Morgan, M. D. 1971. Life history and energy relationships of Hydrophyllum appendiculatum. Ecological Monographs 41:329-349.

Nadelhoffer, K. J., J. D. Aber, and J. M. Melillo. 1985. Fine roots, net primary production, and soil nitrogen availability: a new hypothesis. Ecology 66:1370-1390.

Nemeth, J. C. 1973. Dry matter production in young loblolly (Pinus taeda L.) and slash pine (Pinus elliottii Engelm.) plantations. Ecological Monographs 43:21-41.

Neter, J., and W. Wasserman. 1974. Applied linear statistical models. Richard D. Irwin, Homewood, Illinois, USA.

Nihlgard, B. 1972. Plant biomass, primary production and distribution of chemical elements in a beech and a planted spruce forest in southern Sweden. Oikos 23:69-81.

Nilsen, E. T., and W. H. Muller. 1981. Phenology of the drought-deciduous shrub Lotus scoparius: climatic controls and adaptive significance. Ecological Monographs 51:323341.

Nilsen, E. T., M. R. Sharifi, and P. W. Rundel. 1987. Leaf dynamics in an evergreen and a deciduous species with even-aged leaf cohorts, from different environments. American Midland Naturalist 118:46-55.

Olivares, E. C. 1987. Relaciones hidricas y nutricionales de especies leñosas de bosque deciduo tropical con caracteristicas fenologicas contrastantes. Dissertation. Centro de estudios avanzados, Instituto Venezolano de Investigaciones Cientificas, Caracas, Venezuela.

Oesterheld, M., and S. J. McNaughton. 1988. Intraspecific variation in the response of Themeda triandra of defoliation: the effect of time of recovery and growth rates on compensatory growth. Oecologia (Berlin) 77:181-186.

Ovington, J. D. 1957. Dry matter production of Pinus sylvestris L. Annals of Botany 21:287-316.

Ovington, J. D., and H. A. I. Madgwick. 1959. The growth and composition of natural stands of birch. I. Dry matter production. Plant and Soil 10:271-283.

Pastor, J., J. D. Aber, C. A. McClaugherty, and J. M. Melillo. 1984. Aboveground production and $\mathrm{N}$ and $\mathrm{P}$ cycling along a nitrogen mineralization gradient on Blackhawk Island, Wisconsin. Ecology 65:256-268.
Pastor, J., and J. G. Bockheim. 1981. Biomass and production of an aspen-mixed hardwood-spodosol ecosystem in northern Wisconsin. Canadian Journal of Forest Research 11:132-138.

Pastor, J., and J. G. Bockheim. 1984. Distribution and cycling of nutrients in an aspen-mixed-hardwood-spodosol ecosystem in northern Wisconsin. Ecology 65:339-353.

Peace, W. J., and P. J. Grubb. 1982. Interaction of light and mineral nutrient supply in the growth of Impatiens parviflora. New Phytologist 90:127-150.

Pearson, J. A., T. J. Fahey, and D. H Knight. 1984. Biomass and leaf area in contrasting lodgepole pine forests. Canadian Journal of Forest Research 14:259-265.

Pell, E. J., W. E. Winner, C. Vinten-Johansen, and H. A. Mooney. 1990. Response of radish to multiple stresses. I. Physiological and growth responses to changes in ozone and nitrogen. New Phytologist 115:439-446.

Poorter, H., and C. Remkes. 1990. Leaf area ratio and net assimilation rate of 24 wild species differing in relative growth rate. Oecologia (Berlin) 83:553-559.

Poorter, H., C. Remkes, and H. Lambers. 1990. Carbon and nitrogen economy of 24 wild species differing in relative growth rate. Plant Physiology 94:621-627.

Popma, J., and F. Bongers. 1988. The effect of canopy gaps on growth and morphology of seedlings of rain forest species. Oecologia (Berlin) 75:625-632.

Potter, J. R., and J. W. Jones. 1977. Leaf area partitioning as an important factor in growth. Plant Physiology 59:1014.

Raich, J. W., and K. J. Nadelhoffer. 1989. Belowground carbon allocation in forest ecosystems: global trends. Ecology 70:1346-1354.

Reader, R. J. 1978. Contribution of overwintering leaves to the growth of three broad-leaved, evergreen shrubs belonging to the Ericaceae family. Canadian Journal of Botany 56:1248-1261.

Rehfeldt, G. E., and D. T. Lester. 1966. Variation in shoot elongation of Pinus resinosa Ait. Canadian Journal of Forest Research 44:1457-1469.

Reich, P. B. 1983. Effects of low concentrations of $\mathrm{O}_{3}$ on net photosynthesis, dark respiration, and chlorophyll contents in aging hybrid poplar leaves. Plant Physiology 73: 291-296.

2. 1987. Quantifying plant response to ozone: a unifying theory. Tree Physiology 3:63-91.

Reich, P. B., and R. Borchert. 1982. Phenology and ecophysiology of the tropical tree, Tabebuia neochrysantha (Bignoniaceae). Ecology 63:294-299.

Reich, P. B., and R. Borchert. 1984. Water stress and tree phenology in a tropical dry forest in the lowlands of Costa Rica. Journal of Ecology 72:61-74.

Reich, P. B., and T. M. Hinckley. 1980. Water relations, soil fertility and plant nutrient composition of a pygmy oak ecosystem. Ecology 61:400-416.

Reich, P. B., A. W. Schoettle, H. F. Stroo, J. Troiano, and R. G. Amundson. 1987. Effects of ozone and acid rain on white pine (Pinus strobus) seedlings grown in five soils. I. Net photosynthesis and growth. Canadian Journal of Botany 65:977-987.

Reich, P. B., C. Uhl, M. B. Walters, and D. S. Ellsworth. 1991a. Leaf lifespan as a determinant of leaf structure and function among 23 tree species in Amazonian forest communities. Oecologia (Berlin) 86:16-24.

Reich, P. B., M. B. Walters, and D. S. Ellsworth. 19916. Leaf age and season influence the relationships between leaf nitrogen, leaf mass per area, and photosynthesis in maple and oak trees. Plant, Cell and Environment 14:251-259.

Reiners, W. A. 1972. Structure and energetics of three Minnesota forests. Ecological Monographs 42:71-94.

Rice, S. A., and F. A. Bazzaz. 1989. Growth consequences 
of plasticity of plant traits in response to light conditions. Oecologia (Berlin) 78:508-512.

Robertson, K. P., and H. W. Woolhouse. 1984. Studies of the seasonal course of carbon uptake of Eriophorum vaginatum in a moorland habitat. I. Leaf production and senescence. Journal of Ecology 72:423-436.

Rodin, L. E., and N. I. Bazilevich. 1967. Production and mineral cycling in terrestrial vegetation. Oliver and Boyd, Edinburgh, Scotland.

SAS. 1985. SAS user's guide: statistics. Version 5 edition. S. P. Joyner, SAS Institute, Cary, North Carolina, USA.

Satoo, T. 1970. A synthesis of studies by the harvest method: primary production relations in the temperate deciduous forests of Japan. Pages 55-72 in D. E. Reichle, editor. Analysis of temperate forest ecosystems. Springer-Verlag, New York, New York, USA.

-1979a. Standing crop and increment of bole in plantations of Chamaecyparis obtusa near an electric power plant in Owase, Mie. Japanese Journal of Ecology 29:103109.

1979b. Leaf litter production in plantations of Chamaecyparis obtusa near an electric power plant in Owase, Mie. Japanese Journal of Ecology 29:315-321.

Schlesinger, W. H. 1978. Community structure, dynamics and nutrient cycling in the Okefenokee cypress swamp forest. Ecological Monographs 48:43-65.

Schlesinger, W. H., and B. F. Chabot. 1977. The use of water and nutrients by evergreen and deciduous shrubs in Okefenokee Swamp. Botanical Gazette 138:490-497.

Schlesinger, W. H., E. H. DeLucia, and W. D. Billings. 1989. Nutrient-use efficiency of woody plants on contrasting soils in the western Great Basin, Nevada. Ecology 70:105-113.

Schoettle, A. W. 1990. The interaction between leaf longevity and shoot growth and foliar biomass per shoot in Pinus contorta at two elevations. Tree Physiology 7:209214.

Schulze, E.-D., M. Fuchs, and M. I. Fuchs. 1977. Spatial distribution of photosynthetic capacity and performance in a mountain spruce forest of northern Germany. III. The ecological significance of the evergreen habit. Oecologia (Berlin) 30:239-248.

Shaver, G. R. 1981. Mineral nutrition and leaf longevity in an evergreen shrub, Ledum palustre ssp. decumbens. Oecologia (Berlin) 49:362-365.

- 1983. Mineral nutrition and leaf longevity in Ledum palustre: the role of individual nutrients and the timing of leaf mortality. Oecologia (Berlin) 56:160-165.

Shipley, B., and R. H. Peters. 1990. A test of the Tilman model of plant strategies: relative growth rate and biomass partitioning. American Naturalist 136:139-153.

Shukla, R. P., and P. S. Ramakrishnan. 1984. Leaf dynamics of tropical trees related to successional status. New Phytologist 97:697-706.

Singh, L. P., and R. Misara, editors. 1979. Structure and functioning of natural, modified and silvicultural ecosystems of eastern Uttar Pradesh. Technical Report to UNESCO, Man and the Biosphere. Banaras Hindu University, Varanasi-221005, India.

Small, E. 1972. Photosynthetic rates in relation to nitrogen recycling as an adaptation to nutrient deficiency in peat bog plants. Canadian Journal of Botany 50:2227-2233.

Sollins, P., D. E. Reichle, and J. S. Olson. 1973. Organic matter budget and model for a southern Appalachian Liriodendron forest. Oak Ridge National Laboratory EDFP1BP-73/2.

Son, Y. 1991. Comparison of nitrogen and phosphorus cycling for five plantation-grown tree species with different leaf longevities. Dissertation. University of Wisconsin, Madison, Wisconsin, USA.

Son, Y., and S. T. Gower. 1991. Aboveground nitrogen and phosphorus use by five plantation-grown trees with different leaf longevities. Biogeochemistry 14:167-191.

Sparling, J. H. 1964. Ontario's woodland flora. Ontario Naturalist 2:18-24.

1967. Assimilation rates of some woodland herbs in Ontario. Botanical Gazette 128:160-168.

Sprugel, D. G. 1989. The relationship of evergreenness, crown architecture, and leaf size. American Naturalist 133:465479.

Swank, W. T., and H. T. Schreuder. 1974. Comparison of three methods of estimating surface area and biomass for a forest of young eastern white pine. Forest Science 20:91100.

Sydes, C. L. 1984. A comparative study of leaf demography in limestone grassland. Journal of Ecology 72:331-347.

Tadaki, Y., N. Ogata, Y. Nagatoma, K. Yoshioka, and Y. Miyagawa. 1964. Studies on production structure of forests. VI. Productivities of scaffolding producing stands of Cryptomeria japonica. Journal of the Japanese Forest Society 46:246-253.

Tadaki, Y., N. Ogata, and Y. Nagatoma. 1965. The dry matter productivity in several stands of Cryptomeria japonica in Kyushu. Bulletin of the Government Forest Experiment Station Tokyo 173:45-66.

Taylor, R. J., and R. W. Pearcy. 1976. Seasonal patterns of $\mathrm{CO}_{2}$ exchange characteristics of understory plants from a deciduous forest. Canadian Journal of Botany 54:10941103.

Teskey, R. O., C. C. Grier, and T. M. Hinckley. 1984. Change in photosynthesis and water relations with age and season in Abies amabilis. Canadian Journal of Forest Research 14: 77-84.

Troeng, E., and S. Linder. 1982. Gas exchange in a 20-yearold stand of Scots pine. Physiologia Plantarum 54:7-14.

Tilman, D. T. 1988. Plant strategies and the dynamics and structure of plant communities. Princeton University Press, Princeton, New Jersey, USA.

Turner, J., and P. R. Olsen. 1976. Nitrogen relations in a Douglas-fir plantation. Annals of Botany 40:1185-1193.

Tyrell, L. E., and R. E. Boerner. 1987. Larix laricina and Picea mariana: relationships among leaf life-span, foliar nutrient patterns, nutrient conservation, and growth efficiency. Canadian Journal of Botany 65:1570-1577.

Uhl, C. 1987. Factors controlling succession following slashand-burn agriculture in Amazonia. Journal of Ecology 75: 377-407.

Van Cleve, K., R. Barney, and R. Schlentner. 1981. Evidence of temperature control of production and nutrient cycling in two interior Alaska black spruce ecosystems. Canadian Journal of Forest Research 11:258-273.

Van Cleve, K., and L. L. Noonan. 1975. Litterfall and nutrient cycling in the forest floor of birch and aspen stands in interior Alaska. Canadian Journal of Forest Research 5: 626-639.

Vitousek, P. M. 1982. Nutrient cycling and nutrient use efficiency. American Naturalist 119:553-572.

Vitousek, P. M., P. M. Matson, and K. Van Cleve. 1989. Nitrogen availability and nitrification during succession: primary, secondary and old-field seres. Pages 161-171 in M. Clarholm and L. Bergstrom, editors. Ecology of arable land. Kluwer, Dordrecht, The Netherlands.

Vogt, K. A., C. C. Grier, and D. J. Vogt. 1986. Production, turnover, and nutrient dynamics of above- and belowground detritus of world forests. Advances in Ecological Research 15:303-377.

Vose, J. M., and H. L. Allen. 1988. Leaf area, stemwood growth, and nutrition relationships in loblolly pine. Forest Science 34:546-563.

Walters, M. B., and P. B. Reich. 1989. Response of Ulmus americana seedlings to varying nitrogen and water status. 1. Photosynthesis and growth. Tree Physiology 5:159-172. 
Waring, R. H. 1983. Estimating forest growth and efficiency in relation to canopy leaf area. Advances in Ecological Research 13:327-354.

Waring, R. H., and J. F. Franklin. 1979. Evergreen coniferous forests of the Pacific Northwest. Science 204:13801386.

Wells, C. G., J. R. Jorgensen, and C. E. Burnette. 1975. Biomass and mineral elements in a thinned loblolly pine plantation at age 16. United States Department of Agriculture Forest Service Research Paper SE-126.

Whittaker, R. H. 1966. Forest dimensions and production in the Great Smoky Mountains. Ecology 47:103-121.

Whittaker, R. H., and W. A. Niering. 1975. Vegetation of the Santa Catalina mountains, Arizona. V. Biomass, pro- duction and diversity along the elevation gradient. Ecology 56:771-790.

Williams, K., C. B. Field, and H. A. Mooney. 1989. Relationships among leaf construction cost, leaf longevity, and light environment in rain forest plants of the genus Piper. American Naturalist 133:198-211.

Yoshie, F., and S. Kawano. 1986. Seasonal changes in photosynthetic characteristics of Pachysandra terminalis (Buxaceae), an evergreen woodland chamaephyte, in cool temperate regions of Japan. Oecologia (Berlin) 71:6-11.

Yoshie, F., and S. Yoshida. 1987. Seasonal changes in photosynthetic characteristics of Anemone raddeana, a springactive geophyte, in the temperate region of Japan. Oecologia (Berlin) 72:202-206.

\section{APPENDIX}

Sources of data on leaf life-spans and related traits for the growth $(\mathrm{G})$, height $(\mathrm{H})$, leaves $(\mathrm{L})$, nitrogen $(\mathrm{N})$, and stand $(\mathrm{S})$ data sets. For references listing multiple species, appropriate data were not necessarily available for all species.

\begin{tabular}{|c|c|c|c|c|}
\hline Location & Vegetation type & Species & Data sets & References \\
\hline \multicolumn{5}{|c|}{ Tropical ecosystems } \\
\hline Costa Rica, Guanacaste & Tropical dry forest & 13 tree species & $\mathrm{L}$ & $\begin{array}{l}\text { Reich and Borchert 1982, } \\
1984\end{array}$ \\
\hline India, northeast & Tropical wet forest & 4 tree species & $\mathrm{H}, \mathrm{L}$ & $\begin{array}{l}\text { Shukla and Ramakrishnan } \\
1984\end{array}$ \\
\hline India, Uttar Pradesh & Tropical dry forest & Multiple species & $\mathrm{S}$ & Singh and Misra 1979 \\
\hline Malaysia & Tropical rain forest & Multiple species & $\mathrm{S}$ & Kato et al. 1978, Kira 1978 \\
\hline Mexico, Veracruz & Tropical rain forest & $\begin{array}{l}7 \text { species of Piper } \\
\text { (shrub/tree) }\end{array}$ & $\mathrm{L}, \mathrm{N}$ & $\begin{array}{l}\text { Williams et al. } 1989 \text {, Chaz- } \\
\text { don and Field } 1987\end{array}$ \\
\hline $\begin{array}{l}\text { Panama, Darién } \\
\text { Province }\end{array}$ & Tropical moist forest & Multiple species & $\mathrm{S}$ & Golley et al. 1971 \\
\hline $\begin{array}{l}\text { Phillippines, Mindanao } \\
\text { Island }\end{array}$ & Leucaena plantation & Leucaena leucocephala & $\mathrm{S}$ & Kanazawa and Sato 1986 \\
\hline Tanzania* & Grassland & Themeda triandra & $\mathrm{G}$ & $\begin{array}{l}\text { Oesterheld and McNaughton } \\
1988\end{array}$ \\
\hline Venezuela, Amazonas & Secondary rain forest & Multiple species & $\mathrm{H}, \mathrm{N}, \mathrm{S}$ & Uhl 1987 \\
\hline Venezuela, Amazonas & Tropical rain forest & Multiple species & $\mathrm{N}, \mathrm{S}$ & $\begin{array}{l}\text { Jordan and Uhl 1978, } \\
\text { Klinge and Rodrigues } \\
1968 a, b\end{array}$ \\
\hline Venezuela, Caracas & Tropical dry forest & 10 tree species & $\mathrm{L}, \mathrm{N}$ & Olivares, 1987 \\
\hline \multicolumn{5}{|c|}{ Mediterranean temperate ecosystems } \\
\hline $\begin{array}{l}\text { Canada, British } \\
\text { Columbia }\end{array}$ & Dry temperate & Pinus contorta & $S$ & Comeau and Kimmins 1986 \\
\hline Portugal & Mediterranean & Cistus salvifolius & $\mathrm{L}$ & Harley et al. 1987 \\
\hline Spain & Mediterranean & monspeliensis & $\mathrm{L}, \mathrm{N}$ & Jonasson 1989 \\
\hline USA, Arizona & Coniferous forest & Pseudotsuga menziesii & $\mathrm{s}$ & Whittaker and Niering 1975 \\
\hline USA, Arizona & Desert & Encelia frutescens & $\mathrm{L}$ & $\begin{array}{l}\text { Comstock and Ehleringer } \\
1984,1986\end{array}$ \\
\hline USA, California & Desert & Prosopis glandulosa & $\mathrm{L}$ & Nilsen et al. 1987 \\
\hline USA, California & Desert & 3 winter annual species & $\mathrm{L}$ & $\begin{array}{l}\text { Mooney et al. } 1981 \\
\text { Forseth and Ehleringer } 1982 \\
1983\end{array}$ \\
\hline USA, California & Mediterranean & $\begin{array}{l}\text { Adenostoma fascicula- } \\
\text { tam }\end{array}$ & $\mathrm{L}, \mathrm{N}$ & $\begin{array}{l}\text { Jow et al. } 1980 \\
\text { Mooney and Rundel } 1979\end{array}$ \\
\hline USA, California & Medi & 5 species shrubs/trees & $\mathrm{L}, \mathrm{N}$ & Field et al. 1983 \\
\hline USA, California & Mediterranean & 3 shrub species & $\mathrm{L}, \mathrm{N}$ & $\begin{array}{l}\text { Gray } 1982 \\
\text { Gill and Mahall } 1986\end{array}$ \\
\hline USA, Califo & Mediterranean & parius & $\mathrm{L}$ & Nilsen and Muller 1981 \\
\hline USA, Califc & Mediterranean & $\begin{array}{l}\text { Raphanus sativus } \times \\
\text { raphanistrum }\end{array}$ & $\mathrm{G}$ & Küppers et al. 1988 \\
\hline USA, Canada & Coniferous forest & 25 Pinus sp. & $\mathrm{L}$ & Ewers and Schmid 1981 \\
\hline USA, New Mexico & Deciduous forest & Populus tremuloides & $\mathrm{S}$ & Gosz 1980 \\
\hline USA, New Mexico & Desert & Larrea tridentata & $\mathrm{L}, \mathrm{N}$ & Lajtha and Whitford 1989 \\
\hline USA, Orego & Coniferous forest & Abies species & $\mathrm{s}$ & Fujimori et al. 1976 \\
\hline USA, Rocky Mountains & Coniferous forest & 3 tree species & $\mathrm{L}$ & $\begin{array}{l}\text { DeLucia and Smith } 1987 \\
\text { Carter and Smith } 1988\end{array}$ \\
\hline USA, Washington & Coniferous forest & Abies amabilis & & $\begin{array}{l}\text { Teskey et al. } 1984 \\
\text { Grier et al. } 1981\end{array}$ \\
\hline USA, Washignton & Coniferous forest & $\begin{array}{l}\text { Larix occidentalis } \\
\text { Pinus contorta }\end{array}$ & $\mathrm{L}, \mathrm{N}, \mathrm{S}$ & Gower et al. 1989 \\
\hline
\end{tabular}


APPENDIX. Continued.

\begin{tabular}{|c|c|c|c|c|}
\hline Location & Vegetation type & Species & Data sets & References \\
\hline USA, Washington & $\begin{array}{l}\text { Coniferous forest and } \\
\text { plantations }\end{array}$ & Pseudotsuga menziesii & $S$ & $\begin{array}{l}\text { Cole and Rapp 1981, Keyes } \\
\text { and Grier 1981, Gholz } \\
1982\end{array}$ \\
\hline USA, Washington & Poplar plantation & Populus trichocarpa & $\mathbf{H}$ & Heilman and Stettler 1985 \\
\hline USA, California & Near treeline & Pinus longaeva & $\mathbf{L}$ & $\begin{array}{l}\text { Mooney et al. } 1966 \\
\text { Ewers and Schmid } 1981\end{array}$ \\
\hline USA, Wyoming & Coniferous forests & Pinus contorta & $\mathrm{S}$ & Pearson et al. 1984 \\
\hline \multicolumn{5}{|c|}{ Humid temperate ecosystems } \\
\hline Canada, Ontario & Forest & 10 woody species & $\mathrm{H}$ & Logan $1965 a, b, 1966$ \\
\hline Canada, Ontario & Deciduous forest & 14 forest herbs & $\mathrm{L}$ & Sparling 1964, 1967 \\
\hline Canada, southeastern* & Wetlands & $\begin{array}{l}58 \text { herbaceous angio- } \\
\text { sperm species }\end{array}$ & $\bar{G}$ & Shipley and Peters 1990 \\
\hline China* & Woodland & $\begin{array}{l}\text { Paulownia tomentosa } \\
\text { Populus simonii }\end{array}$ & G & Jia and Ingestad 1984 \\
\hline England & Limestone grassland & $\begin{array}{l}6 \text { grass sp., } 3 \text { dicotyle- } \\
\text { don sp., } 1 \text { sedge sp. }\end{array}$ & $\mathrm{L}$ & Sydes 1984 \\
\hline Europe, New Zealand & Coniferous forest & 3 tree species & $\mathrm{L}, \mathrm{N}$ & $\begin{array}{l}\text { Benecke et al. } 1981 \\
\text { Matyssek } 1986\end{array}$ \\
\hline Germany & Coniferous forest & Picea abies & $\mathrm{L}$ & Schulze et al. 1977 \\
\hline Germany & Hedgerow & 5 shrub species & $\mathrm{L}, \mathrm{N}$ & Küppers $1984 a, b$ \\
\hline Japan & Agricultural ecosystem & Glycine $\max$ & $\mathrm{L}$ & $\begin{array}{l}\text { Miyaji and Tagawa } 1979 \\
\text { Miyaji } 1984\end{array}$ \\
\hline Japan & Deciduous forest & 2 forest herbs & $\mathrm{L}$ & $\begin{array}{l}\text { Yoshie and Kawano } 1986 \\
\text { Yoshie and Yoshida } 1987\end{array}$ \\
\hline Japan & Forest plantation & Cryptomeria japonica & $\mathrm{S}$ & Tadaki et al. 1964,1965 \\
\hline Japan, Sapparo & Deciduous forest & Betula maximowicziana & $\mathbf{S}$ & Satoo 1970 \\
\hline Japan, Sapparo & Deciduous forest & 2 species & $\mathrm{L}$ & Koike et al. 1986 \\
\hline $\begin{array}{l}\text { Japan, Mie and Tochigi } \\
\text { prefectures }\end{array}$ & $\begin{array}{l}\text { Coniferous forest plan- } \\
\text { tations }\end{array}$ & Chamaecyparis obtusa & $\bar{S}$ & $\begin{array}{l}\text { Satoo } 1979 a, b \\
\text { Kawahara et al. } 1979\end{array}$ \\
\hline Northern Japan & $\begin{array}{l}\text { Deciduous forest cano- } \\
\text { py }\end{array}$ & $\begin{array}{l}70 \text { tree and shrub spe- } \\
\text { cies }\end{array}$ & $\mathrm{L}, \mathrm{S}$ & Kikuzawa 1983, 1984 \\
\hline $\begin{array}{l}\text { Sweden, Uppland } \\
\text { Province }\end{array}$ & Deciduous woodland & Betula spp. & $\mathrm{S}$ & Hytteborn 1975 \\
\hline UK, England & Conifer plantation & Pinus sylvestris & $\mathrm{S}$ & Ovington 1957 \\
\hline UK, England & Birch forest & Betula pendula & $\mathrm{S}$ & $\begin{array}{l}\text { Ovington and Madgwick } \\
1959\end{array}$ \\
\hline UK, England* & $\begin{array}{l}\text { Grassland pastures, } \\
\text { woodlands, etc. }\end{array}$ & 26 species & $\mathrm{G}$ & $\begin{array}{l}\text { Jarvis and Jarvis } 1964, \\
\text { Grime and Hunt } 1975, \\
\text { Peace and Grubb } 1982, \\
\text { Kachi and Rorison } 1989\end{array}$ \\
\hline UK, Scotland & Conifer plantations & $\begin{array}{l}\text { Pinus nigra var. mariti- } \\
\quad \text { ma }\end{array}$ & $\mathrm{N}, \mathrm{S}$ & $\begin{array}{l}\text { Miller and Miller } 1976 \\
\text { Miller et al. } 1976\end{array}$ \\
\hline USA & Forests & Several species & $\mathbf{H}$ & Carmean 1975 \\
\hline USA/Canada & Coniferous forest & 12 Pinus sp. & $\mathbf{L}$ & Ewers and Schmid 1981 \\
\hline USA, Georgia & Swamp forest & Taxodium distichum & $\mathrm{N}, \mathrm{S}$ & Schlesinger 1978 \\
\hline USA, Illinois & Deciduous forest & $\begin{array}{l}\text { Hydrophyllum appen- } \\
\text { diculatum }\end{array}$ & $\mathrm{L}$ & Morgan 1971 \\
\hline USA, Illinois & $\begin{array}{l}\text { Early secondary suc- } \\
\text { cessional field }\end{array}$ & 3 species annuals & $\mathbf{L}$ & $\begin{array}{l}\text { Abul-Fatih and Bazzaz } 1980 \\
\text { Mooney et al. } 1981\end{array}$ \\
\hline $\begin{array}{l}\text { USA, Illinois and } \\
\text { Mississippi }\end{array}$ & Forests & Populus deltoides & $\mathbf{H}$ & $\begin{array}{c}\text { Minckler and Woerheide } \\
1968, \text { Krinard } 1985\end{array}$ \\
\hline USA, Maryland* & Agricultural ecosystem & 3 species & $\mathrm{G}$ & Bunce 1989,1990 \\
\hline USA, Massachusetts* & Disturbed field & Abutilon theophrasti & $\mathrm{G}$ & Rice and Bazzaz 1989 \\
\hline $\begin{array}{l}\text { USA, Massachusetts } \\
\text { and North Carolina }\end{array}$ & Forests & Multiple species & $\mathrm{H}$ & $\begin{array}{l}\text { Kozlowski and Ward } 1957 a \\
\quad b\end{array}$ \\
\hline USA, Michigan & Deciduous forest & Populus grandidentata & $\mathrm{S}$ & $\begin{array}{l}\text { Koerper and Richardson } \\
1980\end{array}$ \\
\hline USA, Michigan & $\begin{array}{l}\text { Forest canopy and un- } \\
\text { derstory }\end{array}$ & 10 tree species & $\mathbf{L}$ & $\begin{array}{l}\text { Jurik } 1986 a, b \text {, Jurik et al. } \\
1988\end{array}$ \\
\hline USA, Minnesota & Deciduous forest & Populus tremuloides & $\mathbf{S}$ & Bray and Dudkiewicz 1963 \\
\hline USA, Minnesota & Deciduous forest & Quercus ellipsoidalis & $\mathrm{S}$ & Reiners 1972 \\
\hline USA, Missouri & Deciduous forest & Quercus marilandica & $\mathrm{G}, \mathrm{L}, \mathrm{N}$ & Reich and Hinckley 1980 \\
\hline USA, New Hampshire & Deciduous forest & 9 forest herbs & & Mahall and Bormann 1978 \\
\hline USA, New York & $\begin{array}{l}\text { Agricultural ecosys- } \\
\text { tems }\end{array}$ & Glycine max cultivars & $\mathrm{G}, \mathrm{L}, \mathrm{N}$ & $\begin{array}{l}\text { Amundson et al. 1986, Lugg } \\
\text { and Sinclair } 1981\end{array}$ \\
\hline USA, New York* & Conifer forest & Pinus strobus & $\mathrm{G}$ & Reich et al. 1987 \\
\hline $\begin{array}{l}\text { USA, New York and } \\
\text { North Carolina }\end{array}$ & Deciduous forest & 13 forest herbs & $\mathrm{L}$ & $\begin{array}{l}\text { Taylor and Pearcy } 1976, \text { Ju- } \\
\text { rik } 1980 \text {, Hicks and Cha- } \\
\text { bot } 1985\end{array}$ \\
\hline
\end{tabular}


APPENDIX. Continued.

\begin{tabular}{|c|c|c|c|c|}
\hline Location & Vegetation type & Species & Data sets & References \\
\hline USA, North Carolina & Conifer plantation & Pinus strobus & $\mathbf{S}$ & Swank and Schreuder 1974 \\
\hline USA, North Carolina & Conifer plantation & Pinus taeda & $\mathrm{S}$ & $\begin{array}{l}\text { Nemeth 1973, Wells et al. } \\
1975, \text { Vose and Allen } \\
1988\end{array}$ \\
\hline USA, North Carolina & Deciduous forest & Quercus and other spp. & $\mathrm{N}, \mathrm{S}$ & Day and Monk, $1977 a, b$ \\
\hline USA, Oklahoma & Deciduous forest & $\begin{array}{l}\text { Quercus stellata and } Q \text {. } \\
\text { marilandridica }\end{array}$ & $\mathrm{N}, \mathrm{S}$ & Johnson and Risser 1974 \\
\hline USA, Pennsylvania* & Agricultural ecosystem & Raphanus sativus & G & Pell et al. 1990 \\
\hline USA, Tennessee & Deciduous forest & Several species & $\mathrm{S}$ & $\begin{array}{l}\text { Whittaker 1966, Sollins et } \\
\text { al. } 1973\end{array}$ \\
\hline USA, Virginia & $\begin{array}{l}\text { Deciduous forest un- } \\
\text { derstory }\end{array}$ & $\begin{array}{l}\text { Rhododendron maxi- } \\
\text { mum }\end{array}$ & L & Nilsen et al. 1987 \\
\hline USA, Virginia & Secondary forest & Pinus virginia & $\mathrm{S}$ & Madgwick 1968 \\
\hline USA, Wisconsin & Coniferous forest & Pinus resinosa & $\begin{array}{c}\mathrm{L}, \underset{\mathrm{H}}{\mathrm{N}}, \mathrm{S} \\
\text {, }\end{array}$ & $\begin{array}{l}\text { Bockheim et al. 1983, Reh- } \\
\text { feldt and Lester } 1966\end{array}$ \\
\hline USA, Wisconsin & Deciduous forest & $\begin{array}{l}\text { Populus tremuloides } \\
\text { Acer saccharum }\end{array}$ & $\mathrm{L}, \mathrm{N}, \mathrm{S}$ & $\begin{array}{l}\text { Pastor and Bockheim 1981, } \\
1984\end{array}$ \\
\hline USA, Wisconsin & Oak forest & Quercus species & $\mathrm{S}$ & $\begin{array}{l}\text { G. J. Lawson et al., unpub- } \\
\text { lished data }\end{array}$ \\
\hline \multirow[t]{5}{*}{ USA, Wisconsin } & Deciduous forest & Multiple species & $\mathrm{S}$ & $\begin{array}{l}\text { De Angelis et al. 1981, Pas- } \\
\text { tor et al. } 1984 \text {, Nadelhof- } \\
\text { fer et al. } 1985\end{array}$ \\
\hline & & & $\mathrm{L}, \mathrm{N}, \mathrm{S}$ & Fownes 1985 \\
\hline & & & $\mathrm{H}, \mathrm{L}, \mathrm{N}$ & $\begin{array}{l}\text { P. B. Reich et al., unpub- } \\
\text { lished data }\end{array}$ \\
\hline & & & $\mathrm{L}, \mathrm{N}$ & $\begin{array}{l}\text { Harrington et al. } 1989, \\
\text { Reich et al. } 1991 b\end{array}$ \\
\hline & \multicolumn{3}{|c|}{ Boreal/arctic/northern/taiga ecosystems } & \\
\hline Canada, New Brunswick & Coniferous forest & Pinus banksiana & $\mathrm{N}, \mathrm{S}$ & $\begin{array}{l}\text { MacLean and Wein 1976, } \\
1978\end{array}$ \\
\hline Canada, New Brunswick & Coniferous forest & Abies balsamea & $\mathbf{S}$ & Baskerville 1965 \\
\hline Canada, Newfoundland & Coniferous forest & Picea mariana & $\mathrm{S}$ & Damman 1964,1971 \\
\hline Canada, Ontario & & 3 shrub ericaceous sp. & $\mathrm{L}, \mathrm{N}$ & Reader 1978 \\
\hline Canada, Ontario & Bog, marsh, field & 28 species & $\overrightarrow{\mathrm{L}}, \mathrm{N}$ & Small 1972 \\
\hline Canada, Ontario & Coniferous forest & Picea rubens & $\mathrm{s}$ & Gordon 1981 \\
\hline Canada, Ontario* & Coniferous forest & $\begin{array}{l}\text { Picea glauca, P. mar- } \\
\text { iana }\end{array}$ & $\mathrm{G}$ & Burgess 1990 \\
\hline Canada, Quebec & Coniferous forest & Pinus banksiana & $\mathbf{S}$ & Doucet et al. 1976 \\
\hline $\begin{array}{l}\text { England, Northern } \\
\text { Pennines }\end{array}$ & Peat bog & Eriophorum vaginatum & $\mathrm{L}$ & $\begin{array}{l}\text { Robertson and Woolhouse } \\
1984\end{array}$ \\
\hline Finland & Forests & $\begin{array}{l}\text { Pinus sylvestris, Betula } \\
\text { sp. }\end{array}$ & $\mathrm{S}$ & Mälkönen $1975 a, b$ \\
\hline Scotland, Dumfriesshire & Coniferous forest/bog & Larix species & $\underset{S}{N}$ & Carlyle and Malcom 1986 \\
\hline Sweden & Forests & Fagus, Picea & $\mathrm{S}$ & Nihlgard 1972 \\
\hline Sweden & Forest canopy & Pinus sylvestris & $\mathrm{L}, \mathrm{N}$ & $\begin{array}{l}\text { Linder and Troeng } 1980 \\
\text { Troeng and Linder } 1982\end{array}$ \\
\hline Sweden & Heath, bog & $\begin{array}{l}\text { Dyras octopetala, Empe- } \\
\text { trum hermaphroditum, } \\
\text { Ledum palustre, Rho- } \\
\text { dodendron lapponicum }\end{array}$ & $\mathrm{L}, \mathrm{N}$ & Jonasson 1989 \\
\hline Sweden & Subarctic woodland & 4 shrub sp. & $\mathrm{L}$ & Karlssen 1989 \\
\hline Sweden* & Woodland & Multiple woody species & G & $\begin{array}{l}\text { Ingestad 1976, 1979a, } b \text {, } \\
\text { 1981, Ingestad and Lund } \\
\text { 1979, Ingestad and Kahr } \\
\text { 1985, Agren and Ingestad } \\
\text { 1987, McDonald et al. } \\
\text { 1986 }\end{array}$ \\
\hline USA, Alaska & Taiga forest & Picea mariana & $\begin{array}{l}\mathrm{L}, \mathrm{N} \\
\mathrm{N}, \mathrm{S}\end{array}$ & $\begin{array}{l}\text { Hom and Oechel } 1983 \\
\text { Van Cleve and Noonan } \\
\text { 1975, Van Cleve et al. } \\
1981\end{array}$ \\
\hline USA, Alaska & Tundra & $\begin{array}{l}6 \text { species (shrubs, } \\
\text { sedges) }\end{array}$ & $\mathrm{L}$ & Johnson and Tieszen 1976 \\
\hline USA, Alaska & Tundra & Ledum palustre & $\mathrm{L}$ & Shaver 1981, 1983 \\
\hline USA, Wisconsin & Bog & $\begin{array}{l}\text { Larix laricina, Picea } \\
\text { mariana }\end{array}$ & $\mathrm{L}, \mathrm{N}$ & Tyrrell and Boerner 1987 \\
\hline $\begin{array}{l}\text { USSR, Moscow } \\
\text { Province }\end{array}$ & Deciduous forest & $\begin{array}{l}\text { Betula verrucosa and } \\
\text { other sp. }\end{array}$ & $\mathbf{S}$ & Rodin and Bazilevich 1967 \\
\hline
\end{tabular}

* These studies were conducted under controlled conditions and the location given is of the seed source, or if unavailable, of the institute where conducted. 